\title{
Nationalkamp i nazismens skygge
}

\author{
Af Søren Dall
}

Det danske nazistparti DNSAP og det tyske mindretals nazistparti NSDAP$\mathrm{N}$ fik politisk betydning i magtkampen mellem den danske stat og de tyske myndigheder under Besættelsen af Danmark. Da de to nazistiske partier DNSAP og NSDAP-N havde divergerende nationale politiske mål, bragte dette partierne $i$ et indbyrdes konkurrenceforhold under Besættelsen. Denne artikel bygger på et historiespeciale ved Århus Universitet fra 2010.

»En folketysker fra Nordslesvig hører ikke hjemme i det danske nationalsocialistiske arbejderpartis rækker, men i den tyske folkegruppes politiske organisation. Det er netop folkegruppen, som i dag i grænselandet er den stærkeste bærer af vor førers ideologi for en nyordning af Europa.«1

Så markant var partiføreren for NSDAP-N, Jens Møllers, udmelding om forskellen mellem DNSAP og NSDAP-N i december 1940, da man fra tysk side havde krævet et nærmere samarbejde mellem de to partier. Nazismen fik aldrig en bred folkelig opbakning i Danmark. Det interessante ved de to partier er den position mellem den danske stat og den tyske besættelsesmagt, som Besættelsen bragte dem i. DNSAP blev anvendt som en trussel om en nazistisk magtovertagelse i Danmark over for den danske samlingsregering, mens NSDAP-N var en garant for, at grænsespørgsmålet kunne blive aktuelt igen, og partiet skulle fungere som en slags brobygger mod Norden. Partierne havde divergerende nationale politiske mål, men en fælles ideologi. Artiklen fokuserer på forholdet mellem de to partier under Besættelsen, hvor deres politiske betydning var størst.

\section{Tiden efter 9. april 1940 frem til Werner Bests ankomst efteråret 1942}

Besættelsen af Danmark ændrede forholdet mellem DNSAP og NSDAP-N. For de to partier kom Besættelsen til at betyde nye mulig- 
heder og udfordringer, da den danske stat nu var underlagt en tysk besættelsesmagt. Hos det tyske mindretal i Sønderjylland steg forventningerne til en snarlig grænserevision, mens det danske nazistparti, DNSAP, arbejdede på at overtage magten i Danmark ved hjælp af støtte fra den tyske besættelsesmagt.

I de første uger efter Besættelsen forsøgte begge partier hver især at fremme deres egen nationale politiske sag på bekostning af det andet parti. De blev brikker $i$ et magtspil mellem den danske stat og de tyske myndigheder og mellem konkurrerende tyske instanser. Da den danske regering om morgenen den 9. april 1940 nødtvunget valgte at acceptere de tyske krav, anerkendte man samtidig de tyske myndigheders tilsagn om, at Danmark kunne bevare sin territoriale integritet og politiske uafhængighed. Hermed var det tyske mindretals ønske om en grænserevision foreløbig rykket i baggrunden. Medlemmer af begge partier var samtidig statsborgere i Danmark, hvilket gjorde dem forpligtet til at overholde de danske love. De to partiers politiske handlinger under Besættelsen skal derfor også ses i lyset af det statsretslige perspektiv. ${ }^{2}$

DNSAP og NSDAP-N konkurrerede således om den tyske besættelsesmagts gunst for at realisere de nationale politiske mål. Fra tysk side kom ønsket om frivillige til krigen efterhånden til at stå som et vigtigt punkt $\mathrm{i}$ forhandlingerne med de to partier. Både DNSAP og NSDAP-N arrangerede derfor hver især hvervekampagner for at kunne stå $\mathrm{i}$ et bedre lys hos de tyske myndigheder. Hvervningerne var ikke godkendt af den danske regering, hvilket gjorde, at partierne statsretligt handlede ulovligt over for den danske stat.

Det tyske angreb på Danmark kom som en overraskelse for det tyske mindretal. Overraskelsen blev dog hurtigt afløst af jubelscener, hvor man hyldede de fremrykkende tyske soldater, og hvor medlemmer af NSDAP-N hjalp til med at bevogte tilfangetagne danske soldater. Mindretallet foretog enkelte civile anholdelser, som dog hurtigt blev gjort ugyldige. Der blev hejst hagekorsflag flere steder i Sønderjylland. Et forsøg på at hejse hagekorsflag på Aabenraa Rådhus blev dog stoppet efter kraftig protest fra borgmesteren. I Tønder blev en politibetjent overfaldet af folk fra mindretallet. Derudover kom meldinger fra Haderslev om, at der under afvæbningen af de danske soldater var blevet fjernet en del af det danske militærs våben af tyske nazister. ${ }^{3}$

Det tyske udenrigsministerium havde allerede umiddelbart efter Besættelsen af Danmark truffet forholdsregler, som skulle tages i an- 


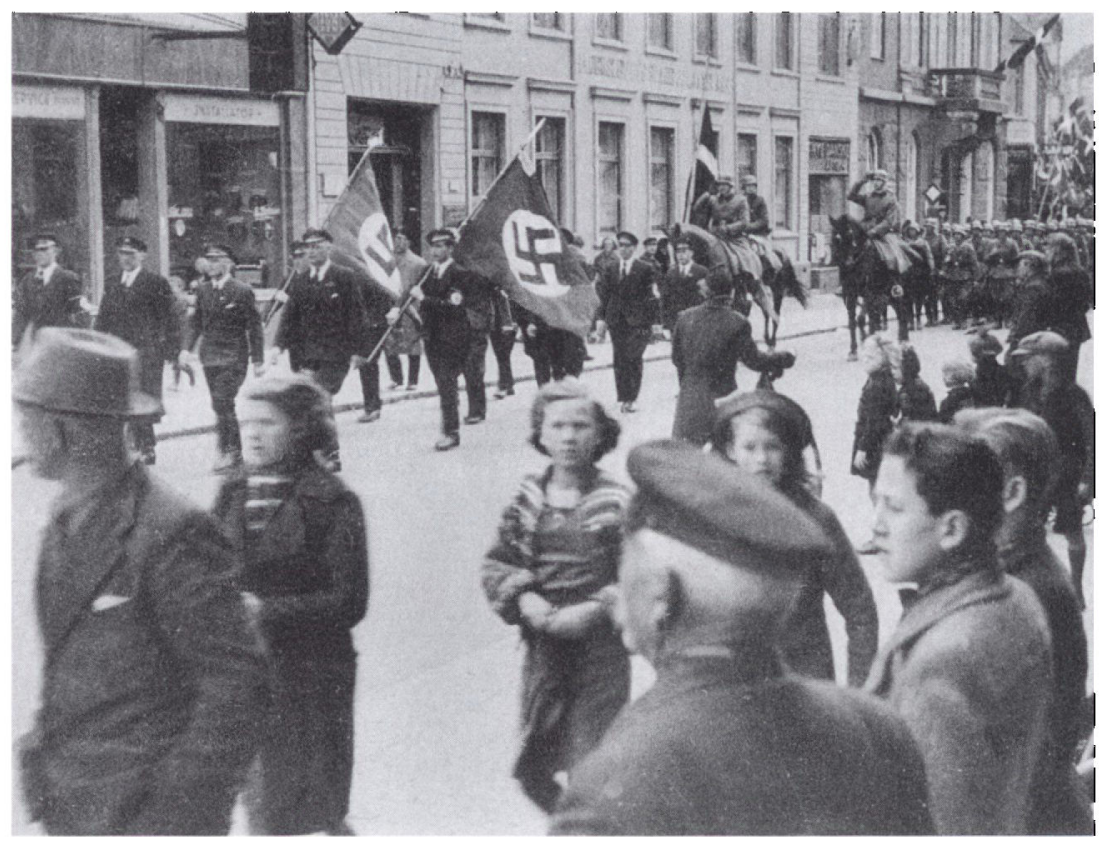

Tysklands besættelse af Danmark den 9. april 1940 fik stor betydning for begge de nazistiske partier, DNSAP og NSDAP-N. Her ses, hoordan de tyske tropper blev modtaget af lokale nazister $i$ Haderslev. Foto: Arkivet ved Dansk Centralbibliotek for Sydslesvig.

vendelse over for det tyske mindretal i Sønderjylland. I et referat skrevet af lederen af $\mathrm{VoMi}^{4}$, Werner Lorenz, den 9. april 1940, hed det, at man havde lovet Danmark territorial integritet $i$ et memorandum, hvilket betød, at grænsespørgsmålet ikke måtte blive taget op af mindretallet. Desuden ville de tyske myndigheder ikke acceptere provokationer eller triumfudbrud, men forventede derimod korrekt opførsel over for de danske myndigheder. ${ }^{5}$

Frits Clausen sendte den 14. april 1940 en redegørelse for sin færden fem dage tidligere til en afdelingsleder i DNSAP. Clausen havde ikke forventet Besættelsen af Danmark. Han noterede sig under sin køretur gennem Sønderjylland, at han blev »... betragtet med stor opmærksomhed og bitterhed hos de fleste...« med undtagelse af enkelte "spytslikkere«, som han betegnede sine egne tilhængere. Det virker derfor, som om han havde forstået hovedparten af danskernes forbitrelse over Besættelsen. Han beskrev efterfølgende situationen, da han 
nåede frem til Folketinget, således: »Rigsdagsmændene var langt nede og folk så frygtsomt og hadsk på os tre nationalsocialister. Vi sad som en isoleret flok i folketingssalen. « Han fortsatte med at beskrive "... Christmas' latterlige sørgmodige, men inderst inde hovmodige ansigt. Hans Hedtofts fuldkommen ynkelige skrækslagenhed «. Frits Clausens tydelige foragt for de øvrige folketingsmedlemmer skinner her tydeligt igennem samtidig med, at fronten mellem de øvrige demokratiske partier og DNSAP var blevet trukket skarpt op. ${ }^{6}$

Beretningen fortsætter med, at de tre nazistiske medlemmer af Folketinget efter folketingsmødet kørte hen på partiavisen Fædrelandets kontor, hvor medlemmer af DNSAP var i heftig diskussion om en aktion foretaget om formiddagen, hvor en ganske lille flok af DNSAP-medlemmer havde besat Christiansborg og efterfølgende var blevet smidt ud af 30 politibetjente. Frits Clausen skrev videre: "Måtte berolige de mest aggressive, selvom jeg af mit hjerte helt var på aggressivisternes side. "Clausen var derefter gået til den tyske gesandt, Cécil von RentheFink, og havde hørt ham om, hvad han mente om situationen i Haderslev efter angrebet og andre småting. Herved skuffede han efter eget udsagn kammeraterne i DNSAP. Clausen pointerede efterfølgende, at »intet ville have været lettere end at tage magten denne aften ... Jeg havde forspildt chancen ved ikke at slå til, da lejligheden var givet «. ${ }^{7}$

Frits Clausen var på den ene side overrasket over Besættelsen, men også indstillet på at anvende de nye muligheder, han havde fået. De 30 danske nazisters forsøg på at besætte Folketinget virkede planløst og ugennemtænkt, og han begyndte i dagene efter Besættelsen at intensivere forsøgene på at overtage magten i Danmark. Samtidig forsøgte han at vise sin danskhed ved at rapportere til udenrigsminister P. Munch om det tyske mindretals handlinger i Sønderjylland i perioden efter det tyske angreb. I et notat fra Justitsministeriet den 16. september 1940 om et forbud mod offentlige moder, fremgik det, at man havde fået informationer fra de danske nazister om, at det tyske mindretal ville arrangere møder, der ville medføre uro. ${ }^{8}$

DNSAP var i de første besættelsesmåneder overbevist om, at det snart ville overtage magten i Danmark. Frits Clausen udtrykte det således $\mathrm{i}$ et notat $\mathrm{i}$ juni 1940: »Begivenhedernes udvikling giver os ret til at forvente, at vi snart vil få overdraget ansvaret for landets økonomiske og politiske genrejsning. "I den følgende tid blev agitationen intensiveret og angrebene på medlemmer af regeringen og andre politiske modstandere optrappet. Clausen skrev i et brev, at »alle 
kræfter skal sættes ind i agitation for vores sag, så det kan tilkendegives, at vores sag hviler på en bred front $\mathrm{i}$ befolkningen«. I et brev fra den 8 . juli 1940 hed det: "Den nye regering har ikke lang levetid ... det skal vi sorge for. «"

I juli startede DNSAP et angreb på de to socialdemokratiske politikere Hans Hedtoft og H.C. Hansen. I en skrivelse til den tyske gesandt i Danmark, Renthe-Fink, den 9. juli 1940, hed det: »Jeg tillader mig at overrække $\mathrm{hr}$. minister en redegørelse for Hans Hedtofts propaganda og spionageaktiviteter." DNSAP's rigsdagsmedlemmer rettede desuden henstilling til Justitsministeriet om indledning af kriminel undersøgelse af socialdemokraten Hans Hedtoft for forbrydelser mod statens sikkerhed. Folketingets formand nægtede dog at forelægge Tinget sagen til behandling på trods af Frits Clausens protest. ${ }^{10}$

I et brev fra september 1940 hed det, at $» D N S A P$ er det eneste alternativ til positionen som tysk protektorat, og vi ville styrte systemet ved egne kræfter og uden tysk hjælp«. I et brev til Frits Clausen den 29. september 1940 hed det videre: "Vi har på det sidste arbejdet hårdt på at blive færdig og kan meddele, at vi har 500 veluddannede SA-mænd klar. Vi venter kun på ordren. Vi håber, vi ikke bliver glemt, men får lov til at være med i det øjeblik, vores elskede Fører tager magten i vores fædreland." DNSAP havde altså en alternativ plan til at komme til magten ved hjælp af den tyske besættelsesmagt. Denne plan skal dog ses som et forsøg på at vise den tyske besættelsesmagt, at partiet havde tilstrækkelig slagskraft til at overtage magten i Danmark. ${ }^{11}$

De tyske myndigheder var skeptiske vedrørende DNSAP som muligt regeringsalternativ til samlingsregeringen. I en anonym tysk notits om DNSAP fra november 1940 hed det: "Deres tyskvenlighed har udgangspunkt $i$ at udnytte konjunkturerne og lade sig løfte $i$ sadlen af tyskerne. Derefter hører deres tyskvenlighed op og viger i forhold til deres nationale program, der er en frontstilling over for Tyskland." Der står desuden, at "den nationale socialistiske bevægelse savner en eller flere fremragende personligheder, den savner autoritet, den savner mulighed for at overbevise de brede masser om sine evner $«$. Den tyske irritation over besværet med at samarbejde med de danske nazister kom her frem. Tyskerne var helt klar over, at DNSAP's motiv for at hjælpe besættelsesmagten var, at den skulle hjælpe partiet til magten. Derudover har Frits Clausens modkrav, for at opfylde de tyske ønsker, sikkert været en irritation for de tyske myndigheder. I et brev til det tyske udenrigsministerium fra det tyske gesandtskab i Køben- 
havn den 29. november 1940 stod der: "Man regner med, at Frits Clausen hverken nu eller $i$ fremtiden har udsigt til at opnå en betydningsfuld vækst i sin bevægelse ... Frits Clausens person er uegnet til at udfolde og udstråle tiltrækningskraft.« Desuden nævntes det også, at man forudså, at modstanden mod Clausen ville vokse, fordi han $\mathrm{i}$ en periode, hvor landet var besat, optrådte "udansk «. ${ }^{12}$

De tyske myndigheder vurderede derved, at Frits Clausen ikke havde udsigt til at få tilstrækkelig opbakning til, at han ville komme til at repræsentere et alternativ til den siddende samlingsregering. Tyskerne har altså haft tvivl om DNSAP's motiver for at være tyskervenlig og været usikre på, om de kunne stole på DNSAP. Den stærke nationalisme i DNSAP har dermed været en faktor, som de har været skeptiske overfor. Samtidig mente de, at DNSAP, ved sin opførsel og angreb på demokratiske danske politikere, havde gjort sig så upopulær i den danske befolkning, at partiet ikke ville kunne opnå en bred opbakning. Hermed blev DNSAP's mulighed for at overtage magten ved hjælp af den tyske besættelsesmagt reelt lukket. De tyske motiver for Besættelsen af Danmark har i første omgang været militære, og besættelsesmagten har derfor haft et pragmatisk syn på Besættelsen, når blot der var ro og orden $\mathrm{i}$ landet. Man vurderede fra tysk side, at det ville koste mere arbejde og skabe uro, hvis DNSAP kom til magten. Det ideologiske fællesskab med DNSAP blev derved sat til side i forhold til andre interesser. Den danske samlingsregering opfyldte de tyske onsker samtidig med, at man mente, at hvis Frits Clausen kom til magten, skulle den tyske besættelsesmagt bruge flere kræfter på at opretholde roen i Danmark.

Både DNSAP og NSDAP-N var overrasket over den tyske besættelse af Danmark, men så hurtigt muligheden for at få opfyldt deres nationale mål ved hjælp af den tyske besættelsesmagt. Mindretallet greb den 9. april 1940 til selvtægt og overtrådte dermed loven i det land, hvor de var indbyggere. DNSAP arbejdede intensivt $i$ tiden efter Besættelsen på at få overbevist besættelsesmagten om at give det magten i Danmark. Den nationale front mellem DNSAP og NSDAP$\mathrm{N}$ blev dermed skærpet, hvilket øgede modsætningsforholdet mellem de to partier. DNSAP havde med Danmarks besættelse faet styrket sin position over for det danske styre. Historikeren Henning Poulsen mener, at de tyske myndigheder overvejede at lade DNSAP overtage magten i Danmark helt frem til valget i 1943. Kilderne synes dog at vise, at den tyske besættelsesmagt reelt havde afskrevet DNSAP som muligt regeringsalternativ i slutningen af $1940 .^{13}$ 


\section{Grænserøret}

Den tyske besættelse af Danmark havde faet mindretallet til at tro, at grænserevisionen var nært forestående. Lederen af VoMi's afdeling for Sønderjylland, Waldemar Rimann, forklarede på et møde den 12. april 1940 partiføreren for NSDAP-N, Jens Møller, at der ikke ville blive tale om en grænserevision. Møller overtalte efterfølgende Rimann til at give beskeden videre til de øvrige ledende medlemmer af mindretallet. Her udtalte Rimann: "I proklamationen til Danmark er spørgsmålet om Danmarks integritet behandlet på en sådan måde, at man ikke mere kan regne med at kunne gennemføre en grænserevision. « ${ }^{14}$ Derved var mindretallets forhåbninger om en grænserevision kommet i baggrunden $\mathrm{i}$ forhold til de generelle forhold mellem Tyskland og Danmark. Samtidig ses, at Møller havde brug for at få repræsentanten for de tyske myndigheder til at forklare den nye situation for de ledende medlemmer af mindretallet. Møller har altså haft behov for, at den øvrige ledelse selv hørte nyheden fra den tyske repræsentant. Dette skyldtes, at Møller ikke ville risikere, at den negative stemning over denne nyhed kunne vende sig mod ham selv.

Efter at skuffelsen over, at grænserevisionen ikke fulgte umiddelbart efter Besættelsen, begyndte forventningerne om en kommende grænserevision igen at stige hos mindretallet. Tysklands angreb på Holland, Belgien og Frankrig den 10. maj 1940 fik betydning for troen på den tyske sejr. Den tyske fremgang på vestfronten medforte, at provinserne Eupen-Malmedy, som Tyskland havde afstået til Belgien efter Versailles-freden, igen blev en del af det tyske rige. Dermed var Sønderjylland det eneste tilbageværende område, som Tyskland havde mistet efter Versailles-freden. Der gik derfor rygter om, at WaffenSS hvervede soldater i mindretallet, som efter endt uddannelse skulle sættes ind ved den dansk-tyske grænse. Desuden var der også interesse for at holde forhåbningerne om en grænserevision i live for at undgå intern splittelse. ${ }^{15}$

Efter Frankrigs fald og det tyske nazistiske flag blev hejst over Versailles den 15. juni 1940, forventede store dele af mindretallet, at Sønderjylland på denne dag ville blive indlemmet $i$ det tyske rige. Der skete dog ikke mere denne dag end, at den nationale kamp i det dansk-tyske grænseområde blev forstærket. Der blev kun registreret forholdsvis beskeden flagning med tyske flag flere steder i Sønderjylland. Der var samtidig blevet rejst flagstænger ved tyske bygninger. 
På et møde den 16. juni 1940 udtalte Jens Møller for NSDAP-N's underførere, at det ikke var tilladt at flage med hagekorsflag. Han tilføjede dog: »I hvert fald ikke før den 28. juni 1940.« Det medførte efterfølgende, at der udbredtes et rygte om, at Sønderjylland skulle blive en del af det tyske rige på denne dag, som var årsdagen for indgåelsen af Versailles-freden efter Første Verdenskrig. Det udløste nærmest en eufori, som fik mindretallets afdelingsleder i Tønder til at udbryde: "I kan hænge mig tre gange, hvis det ikke passer med den 28. juni. «16

De tyske myndigheder havde dog ingen planer om at foretage en grænserevision, og dagen forløb roligt. Mindretallet var skuffet, mens de dansksindede åndede lettet op. Frustrationerne blev vendt mod partiføreren Jens Møller, og en underleder i NSDAP-N udtrykte det således: »Tror De da, hr. Møller vil holde os for nar.« Episoden havde igen øget kløften mellem mindretallet og den øvrige befolkning i grænseområdet. Samtidig havde den kostet Møller prestige og autoritet. $^{17}$

Efter krigen fremlagde Rimann de tre muligheder, som de tyske myndigheder havde haft for at løse grænseproblemet med Danmark. De tyske myndigheder kunne lave en grænseflytning, man kunne udveksle mindretal, eller man kunne indføre dobbelt statsborgerskab for mindretallet. Rimann mente, at rygterne om en grænseflytning i juni 1940 havde fået næring fra de slesvig-holstenske organisationer, der arbejdede på at få grænsen rykket mod nord. Rimann mente desuden, at Møller, ved ikke at stoppe rygterne, bevidst udnyttede den interessemodsætning, som herskede mellem Udenrigsministeriet i Berlin og de slesvig-holstenske organisationer $\mathrm{i}$ Kiel, $\mathrm{i}$ håb om, at den slesvigholstenske linje ville sejre. I slutningen af 1940 kom så udspillet fra de tyske myndigheder, hvor Møller fik at vide, at mindretallets primære opgave fremover var at hjælpe med til, at Tyskland vandt krigen. De tyske myndigheder understregede samtidig, at Møller ikke måtte beskæftige sig med grænsespørgsmålet, da dette spørgsmål hørte ind under det tyske riges udenrigspolitik. Møller fik pålagt, at grænserevisionskravet skulle udgå af mindretallets program. ${ }^{18}$ Derved var dets skæbne bundet til det tyske rige, og det skulle nu give afkald på dets nationale politiske mål. Da grænserevisionskravet var centralt i mindretallets politik, betød det en svækkelse af Møllers position, ligesom NSDAP-N's handlinger havde øget modsætningsforholdet til den øvrige danske befolkning.

Under afhøringen efter Besættelsen mente den tyske gesandt Ren- 


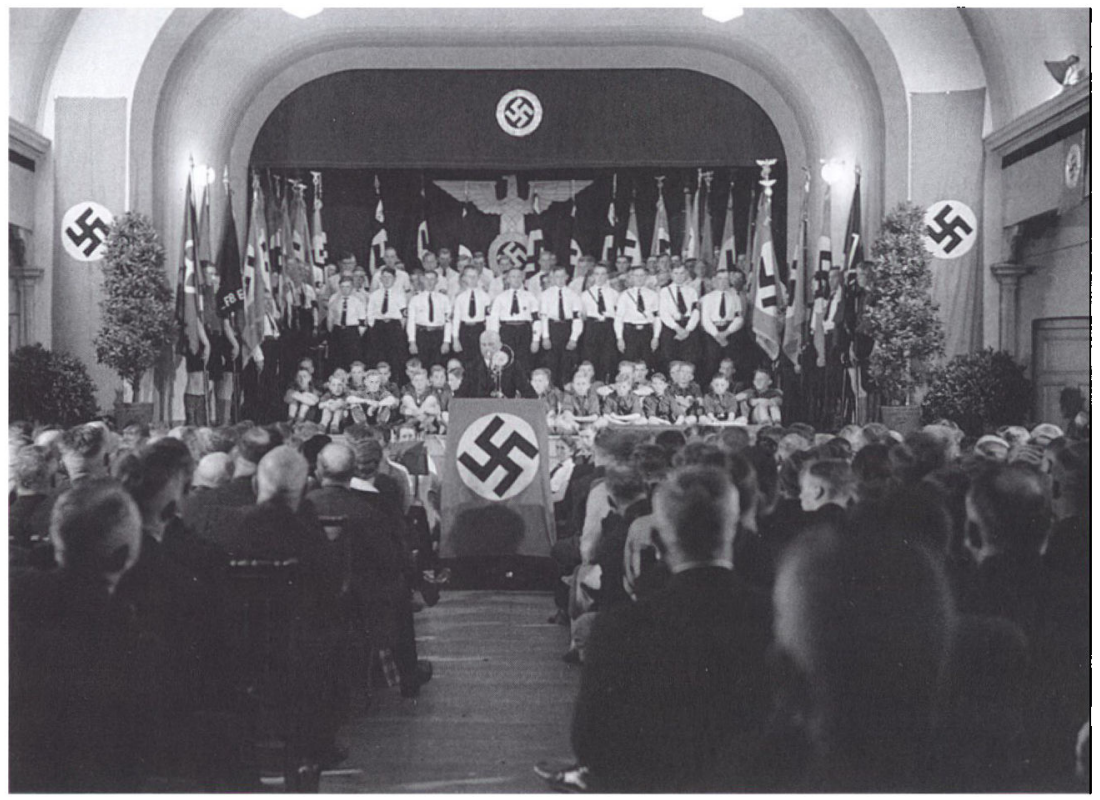

Begejstrede medlemmer af det tyske mindretal modtog de tyske tropper den 9. april 1940. I ugerne efter Besæittelsen havde mindretallet forventninger om, at man kunne fă gennemført kravet om grænserevision. Foto: Museum Sonderjylland - ISL-Lokalhistorie.

the-Fink at have hørt, at mindretallet regnede med, at der ville ske noget den 28. juni 1940, men han tog det ikke specielt alvorligt, da han ikke anså det for muligt, at mindretallet ville gennemføre et kup imod det tyske udenrigsministeriums beslutning i sagen. ${ }^{19}$ Det tyske udenrigsministerium havde villet bevare de forholdsvis rolige forhold i Danmark og var derfor ikke interesseret $i$, at mindretallet skulle skabe uro i grænselandet.

Frits Clausen mente selv i sin beretning efter Besættelsen at han havde været med til at sørge for, at grænserevisionen blev afværget. Clausen mente, at revisionen af den dansk-tyske grænse havde været under kraftig overvejelse, og han skrev i 1947, at han havde overvåget det tyske mindretal i Sønderjylland og givet oplysningerne videre til de danske myndigheder. Clausen mente, at han havde bevirket, at der var blevet sendt over 100 politibetjente til Sonderjylland for at holde orden på mindretallet. Vedrørende rygterne om en grænserevision den 28. juni 1940 skrev han i sin beretning: "Der var kræfter, der 
arbejdede imod, og det var min glæde og stolthed, at jeg havde sat disse kræfter i gang. « $^{20}$ Clausen forsøgte her at fremstå som en handlingens mand. Hans beretning skal ses i forbindelse med, at han sad i fængsel og ventede på sin dom, da den blev skrevet. Von Löw ${ }^{21}$ sagde under afhøringen i 1946, at han sikkert ikke i rette tid havde fået kendskab til mindretallets planlagte demonstration den 28. juni 1940, hvis han ikke havde făet informationen af Clausen. Historikeren John T. Lauridsen påpeger dog, at der kun var tale om rygter i mindretallet, og at det ikke var Clausen, men derimod Renthe-Fink, som fik sat en stopper for det. ${ }^{22}$

For Frits Clausen var situationen i Sønderjylland alvorlig i juni 1940. For at illustrere, hvor langt planerne om grænserevisionen var, henviste han i sin beretning til en rapport fra politiadjudanten i Aabenraa, hvor en ung hjemmetysker fra Haderslev meddelte, at han snart skulle til Østrig for at blive uddannet til politibetjent. Efter endt uddannelse skulle han vende hjem til Sønderjylland og blive betjent, "... når Sønderjylland skal indlemmes under Tyskland «. Clausen mente derfor, at det tyske mindretal var langt $i$ forberedelserne af opbygningen af en administration i Sønderjylland, der skulle tage over, når området igen var blevet en del af det tyske rige. ${ }^{23}$ Der findes dog ingen officielle tyske dokumenter, som viser, at påstanden var andet end et af de mange rygter, der var opstået i Sønderjylland i juni 1940. Frits Clausen anvendte denne episode i sit forsvar efter Besættelsen, hvilket medførte, at han skrev et brev til den tidligere udenrigsminister P. Munch efter Befrielsen. Her håbede han, at Munch ville bekræfte hændelsesforløbet. Munch udtalte efterfølgende under afhøring, at han allerede kort efter Besættelsen var blevet informeret af Frits Clausen om, at det tyske mindretal afholdt møder i Sønderjylland, og at der var uro i landsdelen. Munch nævnte også, at Clausen den 20. juni 1940 igen havde henvendt sig til ham, hvor han fortalte, at han fra en SS-mand havde fået at vide, at der fra tysk side var påtænkt en grænserevision den 28. juni 1940. Munch forklarede videre, at han godt havde hørt, at der var rygter om en kommende grænserevision, men at de oplysninger, som han fik gennem de danske myndigheder i Sønderjylland, ikke var af foruroligende karakter. ${ }^{24}$ Von Löw udtalte dog selv efter Besættelsen, at der ikke var nogen tysk myndighed, som havde haft til hensigt at rejse grænsespørgsmålet i 1940, men at rygterne var kommet fra mindretallet selv. Han mente heller ikke, at Frits Clausen havde gjort noget for at fremme rygterne om en grænserevision. Clausen havde, efter von Löws mening, 
altid været modstander af de kredse i NDSAP-N, som ønskede grænsespørgsmålet rejst. Af afhøringerne efter Besættelsen fremgår, at Frits Clausen og von Löw havde et godt personligt forhold til hinanden under Besættelsen. Von Löw forsøgte derfor sikkert at sætte Frits Clausens handlinger $i$ forbindelse med grænserøret $i$ et godt lys. ${ }^{25}$ Det tyske udenrigsministerium havde, som tidligere nævnt, ikke interesse i at skabe uro i Danmark ved at gennemtvinge en grænserevision. Clausens indberetninger om det tyske mindretals handlinger havde været med til at skabe uro i danske kredse omkring omfanget af begivenhederne $i$ Sønderjylland. Den tyske besættelsesmagt så derfor med stor sikkerhed negativt på, at de danske nazister var med til at besværliggøre situationen i Danmark. Clausens handlinger under grænserøret har sikkert været med til at øge den tyske skepsis over for de danske nazister.

Rygterne om en kommende grænserevision skærpede modsætningsforholdet mellem DNSAP og NSDAP-N, da de to partiers nationale politiske mål her gik i hver sin retning. Mindretallet prøvede at skabe en situation, som ville få de tyske myndigheder til at gennemtvinge grænserevisionen. Der opstod uro og nationale spændinger i grænseområdet, hvilket var imod det tyske udenrigsministeriums ønske om at bevare de forholdsvis rolige forhold, som herskede i Danmark. De tyske myndigheder reagerede ved at kræve, at mindretallet droppede kravet om en grænserevision fra deres politiske program og derimod forpligtede sig til at yde hjælp i den tyske krigsindsats. Derved var mindretallets nationale politiske mål blevet gjort uaktuelt.

De danske myndigheder anvendte de oplysninger, Clausen stillede til rådighed, men kunne samtidig gennem den tyske besættelsesmagt sikre sig, at grænserevisionen ikke var nært forestående. Konkurrenceforholdet mellem DNSAP og NSDAP-N om at få de tyske myndigheder til at opfylde partiernes nationale mål blev derved skærpet. Samtidig var partiernes handlinger medvirkende til, at de tyske myndigheder i realiteten i slutningen af 1940 afskrev begge partier fra at få deres nationale politiske mål opfyldt. De to partier konkurrerede i denne situation om at påvirke de tyske myndigheder i hver sin retning. ${ }^{26}$

\section{Hvervningerne til Waffen-SS}

Initiativet til de tyske hvervekampagner udsprang af både tyske militære og politiske motiver. Hvervningerne i de nordiske lande til Waffen-SS korps blev indledt efter en førerordre den 20. april 1940, men 
kom først i gang i Danmark i maj-juni 1940. Planen var, at det nye korps skulle være en del af Hitlers idé om et storgermansk rige, hvor »herrefolket« skulle bestå både af tyskere og "racebeslægtede« nabofolk, herunder danskerne. Hvervekampagnerne mødte modstand fra den tyske hær og det tyske udenrigsministerium, der ikke mente, kampagnerne var passende samtidig med, at man den 9. april 1940 fra tysk side havde anerkendt den danske suverænitet. Hvervekampagnerne kom i starten til at foregå gennem den nazistiske ledelse i mindretallet og via de danske nazister. ${ }^{27}$

Da Danmark blev besat, kom SS-Standartenführer Müller fra Flensborg over grænsen for at organisere hvervningen af frivillige fra mindretallet til Waffen-SS. Allerede dagen efter Besættelsen gik en intensiv hvervekampagne i gang. Renthe-Fink udtalte efterfølgende, at han principielt var for optagelsen af danske frivillige i tyske militære enheder, men for at undgå vanskeligheder burde hvervningerne begrænses til kun at omfatte medlemmer af det tyske mindretal, de danske finlandsfrivillige og medlemmer af DNSAP. Det var hos medlemmer af disse grupper, at man kunne forvente de bedste muligheder for at få frivillige til Waffen-SS. Den danske lovgivning tillod dog ikke hvervning af frivillige til krigstjeneste, hvorfor man fra tysk side valgte at lade hvervekampagnerne foregå fordækt, således at den egentlige hvervning forst foregik, når de frivillige var blevet fort over grænsen til Tyskland. ${ }^{28}$

De første sessioner i det tyske mindretal blev afholdt i dagene omkring den 22. april 1940. Sessionerne foregik under dække af, at de frivillige skulle deltage $i$ et Wehrsportskursus i Tyskland. Under hvervekampagnerne var flere af de frivillige - efter deres egen mening blevet lovet, at de kun skulle deltage i et tidsbegrænset kursus, hvorefter de kunne vende hjem til landsdelen for at opfylde nærmere bestemte opgaver. I virkeligheden blev de få dage efter ankomsten i Tyskland forelagt en blanket til underskrivelse, hvor de forpligtede sig til at blive tyske statsborgere og gøre tjeneste i SS i flere år. Det fik en del af de frivillige til at vende hjem fra Tyskland. Den 10. juni 1940 kunne politiadjudanten berette, at en person fra mindretallet havde henvendt sig for at få hjælp til at forhindre, at hans søn blev sendt udenlands. Sønnen skulle oprindeligt have meldt sig som frivillig til Tyskland for at blive uddannet til politibetjent. Politiadjudanten konkluderede kort, at der intet ville blive foretaget for at forhindre sønnens udrejse, da han var myndig. Ledelsen af mindretallet vidste 
med stor sandsynlighed besked om, at Wehrsportskurset blot var et dække over tjeneste i SS, da man allerede på dette tidspunkt $\mathrm{i}$ over et år havde samarbejdet med SS omkring hvervning af frivillige. ${ }^{29}$

Renthe-Fink udtalte efter Besættelsen, at opfattelsen inden for SS var den, at der principielt ikke bestod nogen forskel mellem mindretallet og den øvrige danske befolkning, da begge var germanere. SS var derfor inde på tanken om et samarbejde mellem det tyske mindretal og DNSAP. Samarbejdet blev dog aldrig til virkelighed, fordi mindretallet følte sig som tyskere, hvorfor de ikke ville gå ind i et dansk nationalistisk parti. Frits Clausen så samtidig gerne en styrkelse af partiets medlemstal, men han forudsatte, at mindretallet ville rette sig ind efter hans politik. ${ }^{30}$

Forholdet mellem NSDAP-N og DNSAP var anstrengt, da SS ville starte en hvervekampagne af frivillige til Waffen-SS i Danmark. Til stor overraskelse for både Jens Møller og Frits Clausen kontaktede lederen af hvervekampagnen, politipræsident Müller fra Flensborg, Møller, da han skulle tale med Clausen om hvervningen af danske frivillige til SS. Møller kontaktede modvilligt Clausen og deltog i mødet. Da Müller fortalte Clausen, at den planlagte hvervning skyldtes en førerordre, svarede Clausen henvendt til Møller, at »Hitler ikke havde noget at befale her $i$ landet, thi han [Frits Clausen] var dansker og opholdt sig i Danmark «. ${ }^{31}$ Episoden viste, at de to partier ikke var interesseret i det samarbejde, som Hitler og SS forventede af dem.

Frits Clausen var først imod at stå for hvervningen af frivillige til Waffen-SS, men skiftede efterfølgende mening og stillede sit parti til rådighed for denne opgave. I sin egen beretning skrev Clausen, at han efter mødet havde overvejet situationen endnu en gang. Han havde hæftet sig ved, at Møller havde været til stede på mødet. Han så en fare i, at mindretallet ydede et blodoffer for den tyske kamp, mens Danmarks Genrejsningsparti (DNSAP) kun tænkte på smørpriser. Clausen mente, at Sønderjyllands skæbne ville være truet efter en tysk sejr, hvis mindretallet kunne påberåbe sig et ydet blodoffer. Han vidste på det tidspunkt godt, at hvervekampagnerne ville møde modstand i den danske befolkning, men sagde ja af hensyn til Sønderjyllands skæbne efter en tysk sejr. ${ }^{32}$ Konkurrencesituationen mellem NSDAP-N og DNSAP var derfor en vigtig faktor i Clausens beslutning om at bakke op omkring hvervekampagnerne. DNSAP var dog i 1940 hovedsageligt optaget af at overtage magten i Danmark, hvilket gjorde, at partiet ikke gik helhjertet ind i kampagnen. 
Fra den 25. maj 1940 eksisterer der et håndskrevet udkast fra Frits Clausen til Rigskancelliet i Berlin, hvori Clausen bekræftede, at han ville starte hvervningen til SS-regimentet, SS-standarte Nordland. Han stillede dog nogle krav til de frivilliges forhold til Danmark. De frivillige måtte ikke gå tabt for partiet, og de skulle have mulighed for at kunne vende tilbage til Danmark efter tjeneste uden at miste statsborgerskabet. Han anså det samtidig for en naturlig pligt for DNSAP at hjælpe til med hvervningen af frivillige til den tyske krig. ${ }^{33}$ Clausen har på den ene side gerne villet stå godt $\mathrm{i}$ forhold til de tyske myndigheder, men samtidig ikke været interesseret $i$ at miste potentielle allierede i sit forsøg på at få magten i Danmark.

Den 1. september 1940 oprettedes et Waffen-SS rekrutteringskontor i København under ledelse af SS-officeren Erich Lorenz. Hvervekampagnerne mødte modstand fra den danske regering, der syntes, at det havde taget overhånd. Her var man nervøs for, om situationen kunne udvikle sig således, at der kunne komme en nazistisk magtovertagelse i Danmark. De første hvervekampagner havde ikke den store succes, da flere af de frivillige rejste hjem kort tid efter ankomsten til Klagenfurt, hvor den egentlige hvervning skulle foregå. Det skyldtes, at flere af de frivillige havde fået at vide, at de skulle på et skoleophold i Tyskland for at kunne påtage sig en officiel post i Danmark, når Frits Clausen kom til magten, samtidig med at en del slet ikke ønskede at blive soldater. Lorenz mente selv, at den manglende succes skyldtes, at DNSAP koncentrerede sig om den mulige magtovertagelse i Danmark, mens det tyske mindretal frygtede, at det ikke fik den lovede grænserevision, hvis det samarbejdede med de danske nazister. ${ }^{34}$

På et møde i VoMi den 4.-5. december 1940 fik Møller at vide, at mindretallet skulle få skabt en egnet form for forbindelse med Frits Clausens parti, DNSAP. Der blev ikke opsat nogle regler for forbindelsen med DNSAP, men mindretallet skulle handle ud fra øjeblikkets krav og i tæt forbindelse med det tyske gesandtskab i København. Der skulle ikke være nogen officiel forbindelse med DNSAP, og mindretallet skulle afholde sig fra at lave noget, der kunne blive skadeligt for DNSAP i kampen mod Danmarks liberale demokrati. Møller fastholdt dog på et partimøde i NSDAP-N, at grænserne mellem de to partier skulle være klare. En folketysker fra Nordslesvig hørte ikke hjemme i DNSAP, men i det tyske mindretals rækker. ${ }^{35}$

Da det ikke lykkedes DNSAP at overtage magten i Danmark i efteråret 1940, udløste det en intern konflikt i partiet samt oprettelsen af 


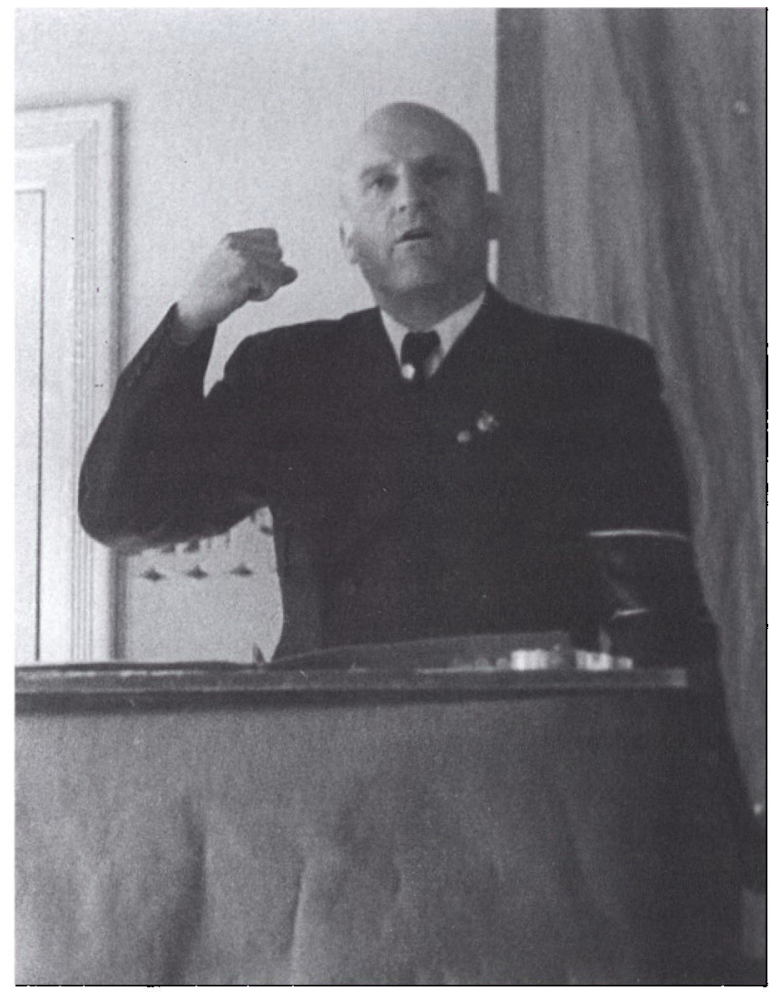

Op gennem 1930'erne blev det tyske mindretal nazificeret og ensrettet. På billedet ses mindretallets forer, Jens Moller, på talerstolen ved et partimøde den 26. september 1943. Foto: Rudolf Gimm. Museum Sønderjylland - ISL-Lokalhistorie.

det konkurrerende danske nazistparti Den danske Front. Det udnyttede Waffen-SS til at få Frits Clausen til igen at gå ind for hvervekampagnerne ved at love, at DNSAP blev det eneste nazistparti i Danmark, der var anerkendt af Waffen-SS. Det var dog et løfte, som ikke kostede Waffen-SS noget særligt, da man ikke fra tysk side tillagde Den danske Front nogen betydning. ${ }^{36}$

Efter forhandlinger med DNSAP og NSDAP-N i februar 1941 om flere frivillige lykkedes det at få begge partier til at lave store kampagner i marts 1941. Frits Clausen havde to møder med Rigsfører Heinrich Himmler i februar og maj 1941, hvilket efter Lorenz' mening gjorde, at Clausen fik stor tillid til SS. Det blev aftalt, at han skulle starte en stor hvervekampagne, og efter Tysklands angreb på Sovjet lavede DNSAP et opråb til kamp mod bolsjevismen. Renthe-Fink ønskede 
samtidig at oprette et Frikorps Danmark, som skulle kæmpe sammen med Finland mod Sovjetunionen. Clausen så i oprettelsen af Frikorps Danmark en mulighed for både at opnå Himmlers velvilje og samtidig få et bevæbnet korps under sin indflydelse, der senere ville kunne anvendes i planerne om magtovertagelsen i Danmark. Clausen valgte derfor at starte en propagandakampagne for en kamp mod bolsjevismen inden for rammerne af Waffen-SS. Himmler greb straks fat $i$ Clausens propagandakampagne og fik den 25. juni 1941 trumfet igennem, at Frikorps Danmark skulle oprettes som et SS-korps. De danske myndigheder var imod oprettelsen af korpset, men den 1. juli 1941 blev der indgået en aftale med de danske myndigheder om korpset. På dette tidspunkt var det dog allerede oprettet. ${ }^{37}$

Den nye hvervekampagne viste sig succesfuld, da der allerede den 19. juli 1941 kunne afsendes et kontingent Frikorps Danmark-soldater fra København. Hvervningens succes skyldtes blandt andet, at antikommunismen havde været en væsentlig drivkraft for en stor del af DNSAP's medlemmer. Derved lykkedes det ifølge Henning Poulsen for Clausen at stabilisere sin position over for de tyske myndigheder. Forholdet til SS blev forbedret, hvilket kunne ses i en mere velvillig holdning til DNSAP's ønske om at få regeringsmagten. ${ }^{38}$ Det var dog samtidig en situation, hvor DNSAP sørgede for frivillige til WaffenSS. SS var interesseret $i$, at DNSAP fortsatte arbejdet med at skaffe frivillige til Waffen-SS, og historikeren Frederik Strand mener, at SS på intet tidspunkt ønskede, at DNSAP fik magten i Danmark. Det skyldtes, at partiets nationalistiske holdninger ville true de tyske visioner om Danmark som del af et storgermansk rige. SS har forsøgt at holde modet oppe hos Clausen, men uden at give ham lofter, da SS reelt ikke har haft interesse $i$, at DNSAP overtog magten. ${ }^{39}$

Frits Clausen fik ny selvtillid af hvervekampagnen til Frikorps Danmark, som han forsogte at anvende til at fremme sin egen politiske sag. Clausen ville have SS til at øve indflydelse på det tyske udenrigsministerium, således at magtovertagelsen ville rykke nærmere. Fra tysk side var man interesseret $i$, at DNSAP ville fortsætte indsatsen med at hverve frivillige til Waffen-SS, men man havde ikke interesse $i$ at fremskynde DNSAP's magtovertagelse i Danmark. I et brev til understatssekretær Martin Luther i forbindelse med Frits Clausens besøg skrev RentheFink, at Clausen havde »... fortjent anerkendelse af det bidrag, som hans parti har ydet i kampen mod den fælles fjende ved at danne de danske frivilligenheder «. Specielt SS gjorde efterfølgende meget for at holde 
humøret oppe hos Clausen, og i efteråret 1941 forsøgte man fra tysk side at øge Clausens autoritet. I en notits fra september 1941 hed det, at rigsføreren for SS, Himmler, havde planer om at indbyde Clausen til et frontbesøg for at styrke hans autoritet inden for DNSAP. Den tyske skepsis over for DNSAP var dog stadigvæk stor. Renthe-Fink skrev den 9. november 1941, at DNSAP foreløbig ikke var i stand til at overtage magten i Danmark, fordi partiet »... savner hjerner, og fordi bevægelsen heller ikke talmæssigt er tilstrækkeligt forankret og underbygget $i$ befolkningen «. Gesandt i det tyske udenrigsministerium, Werner v. Grunherr, skrev den 4. november 1941 om holdningen i Danmark til DNSAP: "Derimod er det danske kongehus', den danske regerings og næsten hele det danske folks holdning afvisende over for DNSAP og Clausen, hvis førerevne ikke anerkendes. ${ }^{40}$

Den tyske afvisning af Frits Clausen skal ses i forhold til situationen, som herskede i Danmark. Den tyske udenrigsminister, Joachim v. Ribbentrop, beskrev den 11. november 1941 forholdene i Danmark således: »I intet af de af os besatte lande hersker der en sådan ro og et så snævert, næsten gnidningsløst samarbejde som i tilfældet Danmark.« Derudover krævedes der kun et ringe antal tyske styrker til at bevare roen i Danmark. ${ }^{41}$ Det var altså vigtigere for det tyske udenrigsministerium, at der herskede forholdsvis rolige forhold $i$ Danmark, som ikke krævede store tyske ressourcer, end et nazistisk styre. Henning Poulsen mener, at Clausens værdi for tyskerne var blevet større, og interessen for partiet øget. Clausens manglende opbakning hos den danske befolkning samt en tysk mistillid til Clausens lederegenskaber var fortsat en forhindring $i$ hans ønske om magten $i$ Danmark. Til dette kom også det faktum, at krigen nu så ud til at trække i langdrag, især på østfronten. ${ }^{42}$

De tyske tropper led store tab på østfronten i vinteren 1941/42, hvilket gjorde det nødvendigt for Waffen-SS at fylde rækkerne op med nye frivillige. Hvervekampagnerne blev i starten af 1942 afbrudt af Frits Clausen, som ikke var tilfreds med situationen. Renthe-Fink beskrev i et telegram den 6. februar 1942 en samtale med Clausen. Her beklagede Clausen sig over den fjendtlighed, som hans parti og de danske frivillige blev udsat for fra dansk side, samt den ikke tilstrækkelige støtte fra tysk side. Han forlangte desuden, at forsvarsministeren og justitsministeren i den danske regering skulle udskiftes. Clausen ville stoppe hvervningen af frivillige fra DNSAP's egne rækker for at kunne forsvare sig mod de danske myndigheder. Han ville 
samtidig bede Himmler om at sende en del af de frivillige hjem igen. Clausen forsøgte at presse Renthe-Fink til at give indrømmelser, således at han kunne hævde sin position i forhold til resten af DNSAP. Hans utålmodighed med de manglende politiske resultater fik ham altså til at anvende truslen om at stoppe hvervninger for at få sine ønsker igennem. Clausens handlinger tyder på, at han var presset og havde brug for resultater. Renthe-Fink kom selv ind på, at utilfredsheden skyldtes, at Quisling samtidig havde fået overdraget regeringsmagten i Norge. Renthe-Fink svarede igen ved at fraråde Clausen at lægge sig fast på krav, som kun kunne gennemføres ved tysk hjælp. Desuden meddelte Renthe-Fink, at man fra tysk side forventede, at Clausen indordnede sit politiske arbejde under de tyske interesser. ${ }^{43}$ Hermed ses, at DNSAP's position over for det tyske gesandtskab i København ikke havde forbedret sig på trods af partiets indsats i forbindelse med hvervekampagnerne, og at Clausens forsøg på at styrke sin position blev mødt med en markant tysk afvisning.

Den 5. februar 1942 meddelte DNSAP's hovedkvarter, at hvervninger af frivillige til østfronten skulle ophøre på grund af indtrufne forhold, men den 19. februar blev de genoptaget, og fra marts 1942 kom der fart på hvervningerne. Christian v. Schalburg overtog ledelsen af Frikorps Danmark i marts 1942 og blev hurtigt en populær leder af korpset. Samtidig var han loyal over for DNSAP og erklærede, at hans mål var at skabe et nationalsocialistisk korps. I en særbefaling fra SAstabschef Axel Juul den 12. maj 1942 hed det, at "for fă dage siden indsattes Frikorps Danmark mod de røde horder «. Det satte endnu mere fart på hvervningerne. I en særbefaling fra den 26. maj 1942 hed det: »Partiføreren har ønsket, at alle partimedlemmer såvel som førere og ledere melder sig til Våben SS. Der er ingen af jer, som er uundværlig, og i dette år afgøres Danmarks skæbne. Ingen fører i SA, der ikke har gyldig undskyldning for sin forbliven i Danmark, kan fra i dag forvente en fremtid inden for partiet eller SA, når Europas og Danmarks skæbne afgøres på østfronten. « ${ }^{\mathbf{4}}$

Det var meget tydeligt, at hvervekampagnerne blev et centralt omdrejningspunkt for DNSAP's propaganda i 1942. Frits Clausen så korpset som en mulighed for at få indflydelse på et militært korps, som kunne anvendes i DNSAP's kamp for at få magten i Danmark. Den 26. april deltog medlemmer af Frikorps Danmark i et stort anlagt DNSAP-møde i København for at gøre propaganda, hvilket den tyske værnemagt var utilfreds med, da de frivillige optrådte som partitrop- 


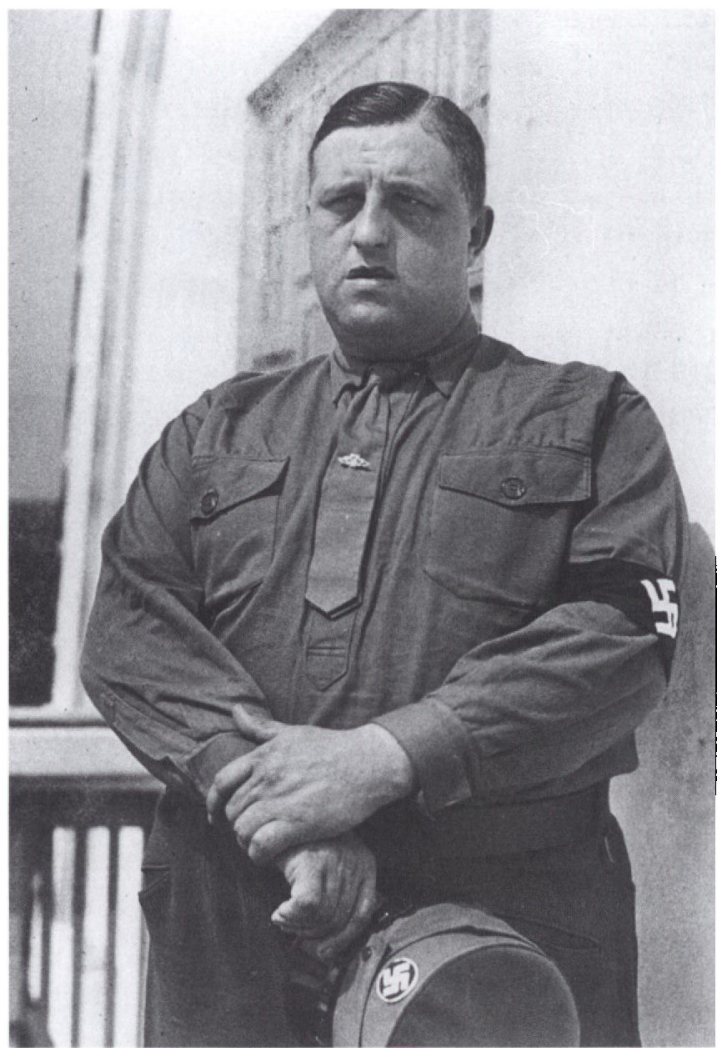

Fritz Clausen, der forsogte at benytte den tyske besættelsesmagt til at komme til magten i Danmark. At det ikke lykkedes, skyldtes $i$ væsentlig grad, at forskellige tyske myndigheder så skævt til DNSAP på grund af partiets dansknationale linje. Foto: Museum Sønderjylland - ISL-Lokalhistorie.

per for DNSAP. Partiet brugte alle midler til at få sin propaganda igennem. Der blev fingeret et knivoverfald på et medlem af Frikorps Danmark for at fremme DNSAP's partiinteresser og fremkalde et billede i Tyskland af, at situationen i Danmark var ude af kontrol. DNSAP's propaganda fik dog den modsatte effekt end den, der var tiltænkt, da der bredte sig en opfattelse i den danske befolkning af, at den tyske værnemagt havde en beskyttende holdning over for DNSAP's ulovlige handlinger. ${ }^{45}$

Hvervekampagnerne startede for DNSAP's vedkommende for at undgå, at mindretallets nazistparti, NSDAP-N, skulle komme til at stå 
bedre over for de tyske myndigheder. SS ønskede, at de to partier fik et tættere samarbejde, hvilket især NSDAP-N modarbejdede. Da Tyskland i juni 1941 angreb Sovjetunionen, kunne DNSAP finde en sag at samles om. Man forsøgte efterfølgende at styrke sin position ved at anvende hvervekampagnerne som pressionsmiddel, hvilket dog ikke medførte det ønskede resultat, da de tyske myndigheder bevarede deres skepsis over for DNSAP. Hvervekampagnerne optrappede konkurrencesituationen mellem de to partier, da de begge var villige til at gå langt for at komme til at stå godt hos de tyske instanser. Frits Clausens forsøg på at opnå indrømmelser fra de tyske myndigheder ved at udnytte hvervekampagnerne slog fejl og viste, hvor svagt han reelt stod over for de tyske myndigheder. Derimod lykkedes det til sidst mindretalsledelsen at undgå, at de frivillige fra mindretallet blev optaget i Frikorps Danmark. Partiet havde derfor lettere end DNSAP ved at fremme dets egen sag over for de tyske myndigheder.

\section{Førerkrisen i det tyske mindretal}

I slutningen af 1940 kom det til et brud i SS samarbejde med mindretallet om at skaffe frivillige til Waffen-SS. Dette skyldtes, at mindretallet anså SS' hensyntagen til de danske nazister og tanken om Hitlers storgermanske rige som grund til, at grænserevisionen endnu ikke var gennemført. Det medførte, at mindretallet var meget skeptisk over for SS' racemæssige argumenter for at hverve frivillige blandt de danske nazister. SS tog ikke specielt hensyn til mindretallet i hvervekampagnerne, men samarbejdede både med DNSAP og NSDAP-N på samme tid. ${ }^{46}$

Da Erich Lorenz blev leder af SS' hvervekontor i København i september 1940, fortsatte han SS' ideologiske hvervepolitik, som totalt ignorerede det nationale modsætningsforhold mellem NSDAP-N og DNSAP. Lorenz tog derfor kontakt til Chr. Paysen fra NSDAP-N, der, modsat ledelsen i mindretallet, gik ind for et nærmere samarbejde mellem de to nazistiske partier omkring Hitlers storgermanske rige. Det skabte et anspændt forhold mellem mindretallets ledelse og SS. Lorenz skrev i en rapport: "... dass eine verschärfte Spannung zur deutschen Volksgruppe in Nordschleswig entstand, die durch das oppositionelle Verhalten eines Mitgliedes des Parteirates hier bekannt wurde». ${ }^{47}$ Det tyder på, at DNSAP var blandet ind i situationen. I et brev fra Paysen til Frits Clausen den 21. november 1940 hed det: 
"Udviklingen i min sag i forbindelse med SS er i stadig fremmarch “, hvilket hentyder til den pjece, han udgav i vinteren 1941 om den storgermanske idé i det dansk-tyske grænseområde. ${ }^{48}$ Clausen vurderede sikkert, at planen om det storgermanske rige kunne give ham kontrollen over NSDAP-N, da SS ikke så den store ideologiske forskel mellem de to partier. Jens Møller fortalte selv efter Befrielsen, at han ekskluderede $\mathrm{Chr}$. Paysen fra mindretallets store rådgivende politiske råd i efteråret 1940, da han opdagede, at Paysen røbede rådets forhandlinger til Clausen. Derudover var Paysen tilhænger af et nært samarbejde mellem DNSAP og NSDAP-N. Gottlob Berger fra VoMi var meget interesseret $i$ et sådant samarbejde, hvilket medførte, at SS var utilfreds med Møllers politik og ønskede ham fjernet som leder af mindretallet. Jens Møller fortalte selv, at SS var utilfreds med, at han ikke stillede en lige så stor andel frivillige til rådighed for WaffenSS som de øvrige tyske mindretal i Europa samtidig med, at han erklærede flere af de frivillige, som havde meldt sig, for uundværlige. Ifølge Møller kontaktede SS derfor Peter Larsen fra mindretallet med henblik på at få Møller fjernet som leder. Larsen skulle derefter have erklæret, at han selv ville træde tilbage fra sin post som leder af Organisationsamt, hvis VoMi fjernede Møller som leder. Møller fandt senere ud af, at Paysen stod bag en indberetning til SS om, at Møller modarbejdede SS' interesser i Danmark. ${ }^{49}$ SS var irriteret over Jens Møllers tilbageholdende politik i forhold til hvervningen og sonderede derfor mulighederne for at erstatte Møller med en mand, som ville være mere samarbejdsvillig. VoMi nåede dog selv frem til, at det ikke ville være i dets interesse at fjerne Møller i 1941. Det skyldtes, at man ikke havde en potentiel alternativ leder samtidig med, at det var VoMi selv, som havde indsat Møller som leder af mindretallet og opbygget hans position. Desuden var det i februar 1941 lykkedes - efter en længere pause - at få genoptaget hvervekampagnerne i mindretallet.

I forbindelse med at de tyske tropper i vinteren 1941/42 led store nederlag på østfronten, skulle Møller i starten af 1942 offentligt opfordre til, at unge mennesker fra mindretallet meldte sig til Waffen-SS. Møller var bevidst om, at hvervekampagnen var upopulær, hvilket blandt andet skyldtes, at den tyske hærs problemer på østfronten ville udskyde en løsning af grænsespørgsmålet. Møller forsøgte derfor at få håbet om grænsespørgsmålet draget ind i sit opråb. I den originale udgave af opråbet i februar 1942 hed det: "Tysklands skæbne er vor 
skæbne. Den er vor hjemstavns skæbne.« Det fik det tyske udenrigsministerium til at kræve de sætninger fjernet, der hentydede til håbet om grænserevisionen. Det skyldtes hensyn til hvervningen blandt de danske frivillige, som kørte på samme tid. Møller formulerede samtidig opråbet således, at det forpligtede samtlige tysksindede til at melde sig som frivillige. ${ }^{50}$

Modstanden mod hvervekampagnerne var samtidig vokset i mindretallet. Politiadjudanten skrev den 5. december 1941: »Der er ved forskellige lejligheder udtalt, at der inden for mindretallet er kommet en animositet til orde mod folketingsmedlem Jens Møller.« Det skyldtes, at han i agitationen for frivillige til den tyske hær skulle have pointeret, at det kun drejede sig om tjenesten i en slags hjælpetropper, der ikke skulle befinde sig i frontlinjen. De 40-50 faldne på dette tidspunkt viste imidlertid, at de frivillige anvendtes i stormtropperne, hvilket vakte bestyrtelse. I sin indberetning den 6. december 1942 konkluderede politiadjudanten, at hvervningen nu havde karakter af tvangsudskrivning, og at en meget væsentlig fraktion i mindretallet var stærkt imod denne aktion. ${ }^{51}$ Jens Møller var derfor udsat for et internt pres i mindretallet. Paysen udnyttede denne situationen til at udgive et nyt skrift, hvori han igen skrev om den storgermanske tanke i det dansk-tyske grænseområde. Han angreb forestillingen om, at de frivillige kæmpede for en grænserevision.

Paysen skrev, at de frivillige "... nicht für eine ungerechte Grenzrevision kämpfen. Die egoistischen Grenzrevisionsziele der Parteileitung seien nicht die Ziele der kämpfende Truppe, sondern die Volksdeutschen Nordschleswiger kämpfen für Deutschland und für ein Grossgermanisches Reich «. ${ }^{52}$ De frivillige havde altså ikke »... partiledelsens egoistiske grænserevisionsmål...", men kæmpede for "... Tyskland og et stortysk rige". I Paysens skrift var der flere personlige angreb på mindretallets ledelse og andre navngivne mennesker samt på mindretallets politiske dispositioner. Skriftet rummede yderligere flere opfordringer til et nært samarbejde med DNSAP. »Mit Frits Clausen aus nationalsozialistischer Grundlage zusammenzufinden auf einen gemeinsamen Weg... Unter Frits Clausen war von Anfang an das Bekenntnis zur deutsch-nordischen Einheit das vorherrschende. ${ }^{53}$ De tyske myndigheder blev nu nødt til at reagere over for Paysen, da hvervningerne i mindretallet var truet. I et brev fra den tyske konsul i Aabenraa, Ewald Lanwar, til det tyske gesandtskab i København stod der, at da Jens Møller var indsat af VoMi og udelukkende 
udførte instrukser og ordrer fra Berlin, var det »... alene af hensyn til anstændigheden nødvendigt...", at Møller blev beskyttet af VoMi. Det var i forvejen svært for de tyske myndigheder at "... lede folketyskernes blik bort fra grænsen og over på det, der sker i storpolitikken«. Lanwar tog ikke afstand fra Paysens tanker, men mente, at de skulle gennemføres langsomt, forsigtigt og med tålmodighed. ${ }^{54}$

Sagen blev efterfølgende forelagt Himmler, som krævede, at Paysen blev indkaldt til den tyske værnemagt samtidig med, at skriftet blev inddraget. Derudover gav Himmler Møller sin fulde opbakning. Møller mistænkte dog stadigvæk SS for at stå bag Paysens angreb og krævede nu - som tidligere nævnt - at mindretallets frivillige ikke blev optaget i Frikorps Danmark, men optaget i regulære tyske SSformationer. Møllers krav blev imødekommet fra SS, der dog ikke forsikrede mindretallet om, at grænserevisionen blev gennemført, men holdt håbet åbent. ${ }^{55} \mathrm{SS}$ var altså på tilbagetog over for mindretallets ledelse angående samarbejdet med DNSAP. Samtidig kan SS have erkendt, at man var nødt til at spille på håbet om en grænserevision for at kunne holde hvervningerne i gang. SS var presset af behovet for flere frivillige, hvilket har gjort, at de valgte at give efter for mindretalsledelsens krav. NSDAP-N stod stærkere over for de tyske myndigheder end DNSAP, som havde vanskeligt ved at overbevise om, at det var et alternativ til den danske samarbejdspolitik.

Modsætningsforholdet mellem de to partier var vokset i perioden, hvor selve NSDAP-N's nationale politiske mål var truet af SS' ønske om et tættere samarbejde mellem de to partier. SS valgte at bøje sig for Møllers krav, da selve hvervningerne i mindretallet var truet. Dette vidner om, at NSDAP-N havde formået at anvende hvervningerne til at styrke deres position over for SS, mens DNSAP gennem hvervningerne ikke var kommet tættere på at få magten i Danmark.

\section{Tiden efter Werner Bests ankomst}

Der var kommet en voksende modstand i den danske befolkning mod hvervekampagnerne i 1942, og modstanden mod den tyske besættelsesmagt var taget til i omfang. Der var sket en stigning $i$ antallet af sabotageaktioner i Danmark i 1942, hvilket var medvirkende til, at man fra tysk side markerede, at der var grænser for, hvor tålmodig besættelsesmagten var over for den danske regering.

Anledningen til at stramme besættelsespolitikken kom i forbindelse 
med Telegramkrisen i september 1942. Krisen startede med, at Hitler sendte Christian $X$ et lykønskningstelegram $\mathrm{i}$ forbindelse med hans fødselsdag den 26. september 1942. Den samme aften kom et kortfattet svar, der lød: "Udtaler min bedste tak. Christian R.« Det kortfattede svar udløste den hidtil alvorligste krise under Besættelsen. Hitlers første reaktion på Telegramkrisen var at kræve, at Frits Clausen blev trukket helt frem i forreste række for at overtage magten i Danmark. Det tyske gesandtskab var dog fortsat skeptisk over for DNSAP's politiske muligheder.

Telegramkrisen medførte efterfølgende, at den rigsbefuldmægtigede blev udskiftet, og den 2. oktober 1942 ankom den nye øverstbefalende for de tyske tropper i Danmark, general v. Hanneken. Han havde fået instrukser om, at erklæringerne fra den 9. april 1940 om forholdet mellem Danmark og Tyskland ikke gjaldt mere, da krigen trak ud. Samtidig ville Danmark efter krigen blive en tysk provins. Den nye rigsbefuldmægtigede ville samtidig komme til et land, som nu blev betegnet som fjendeland. Der skulle desuden indsættes en nazistisk regering under ledelse af DNSAP. Overordnet skulle den tyske værnemagt fremover ikke mere komme med ønsker, men stille krav, og modstand skulle slås ned med hård hånd. ${ }^{56}$ SS-officeren Werner Best blev indsat som ny rigsbefuldmægtiget i Danmark. Best var formelt underlagt det tyske udenrigsministerium, men brugte flere gange sin position som SS-officer til at gå uden om det tyske udenrigsministerium, hvis det passede ind $\mathrm{i}$ hans interesser. Werner Bests første opgave i Danmark blev at afslutte Telegramkrisen, og han fik instrukser om at forandre den tyske politik i Danmark. Han skulle indsætte en mere tyskvenlig regering samt intensivere forberedelsen af indsættelsen af en nazistisk regering. På trods af Frits Clausens forsøg på at få nazistiske ministre med i den nye regering endte det med, at Scavenius dannede en ny samlingsregering uden nazister. ${ }^{57}$

Schalburgkorpsets oprettelse i februar 1943 betød, at Frits Clausen mistede sin position i forhold til hvervningerne. Gottlob Berger ville med oprettelsen af korpset skabe et politisk alternativ til samarbejdet med DNSAP, som han ikke fandt tysksindet nok. Best kaldte korpset "... en ny gruppe ... i hvilken efter aftale med alle nationalsocialistiske partier og foreninger i Danmark alle mænd, der er indsatsduelige for politiske mål, kan indtræde«. Clausen fik ingen indflydelse på oprettelsen af Schalburgkorpset, og med Frikorps Danmarks opløsning mistede Clausen et samlet aktivt korps, hvis loyalitet han kunne 
håbe på. Herved havde Clausen mistet sin indflydelse på hvervningerne. ${ }^{58}$ Folketingsvalget den 23 . marts $1943 \mathrm{blev}$ derefter Frits Clausens sidste chance for at vise sig som en mulig samarbejdspartner for de tyske myndigheder. Det lykkedes dog ikke DNSAP at opnå fremgang ved valget. Den danske befolkning havde tværtimod valgt at bakke op om de partier, som stod for samarbejdspolitikken. Herved var DNSAP ude af det politiske spil. Det tyske mindretal så Werner Bests ankomst til Danmark som en god mulighed for at opnå en større autonomi i forhold til den øvrige del af det danske samfund. Folketingsvalget i marts $1943 \mathrm{blev}$ anledning til at få ønskerne igennem, men for Best var det en mulighed for at styrke Scavenius-regeringens position gennem folkelig opbakning. Derudover kunne de danske nazister få mulighed for et fremstød i Danmark. Mindretallet krævede ved valget, at der blev oprettet et tysk kontor under Statsministeriet, som skulle tage sig af mindretallets anliggender. Kontoret blev efterfølgende oprettet på trods af dansk modstand. ${ }^{59}$

\section{Clausens og Møllers forhold til Werner Best}

For at kunne beskrive Frits Clausens forhold til Werner Best er det nødvendigt at se på Clausens politiske handlinger under Telegramkrisen og de tyske reaktioner herpå. I starten af Telegramkrisen var Clausen bekymret for, hvad der nu skulle ske. Ved at kontakte den tyske chargé d'affaires Paul Barandon den 10. oktober 1942 udnyttede han dog situationen til at foreslå, at DNSAP overtog magten i Danmark. Statssekretær Ernst v. Weizsäcker i det tyske udenrigsministerium mente dog, at en nazistisk magtovertagelse i Danmark på dette tidspunkt ville være forhastet og en fejl. ${ }^{60}$ Barandon beskrev den 15 . oktober 1942 stemningen i Danmark som præget af nervøsitet. Barandon mente ikke, at tiden var kommet til en nazistisk magtovertagelse, men at man skulle have en overgangsregering, der ville være villig og i stand til at gennemføre de tyske ønsker. Den 26. oktober 1942 skrev understatssekretær Martin Luther, at Clausen frygtede, at Scavenius' forsøg på at danne en regering havde til formål at udelukke ham. Clausen havde samtidig erklæret, at han stod til rådighed for alle andre løsninger. Han var dog betænkelig ved en protektorat-løsning, da denne ville møde stærk modstand i den danske befolkning og i hans eget parti. ${ }^{61}$

Det lykkedes Scavenius at oprette en regering uden ministre med 


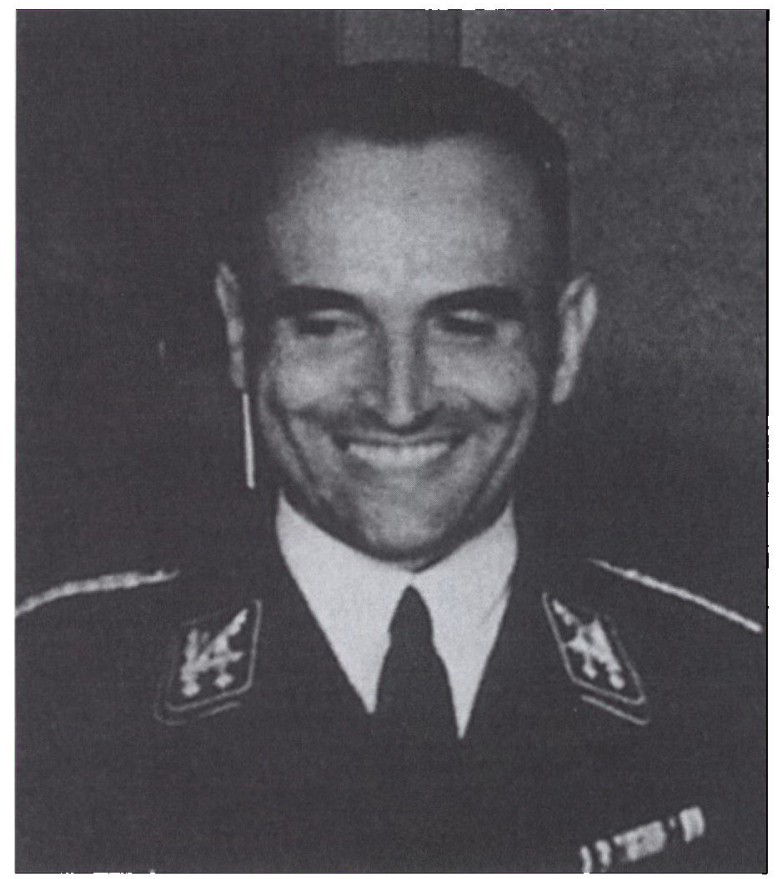

På billedet ses Werner Best, der blev udnæont til tysk rigsbefuldmægtiget $i$ Danmark $i$ efterairet 1942. Best udviklede et godt forhold til lederen af NSDAP-N, Jens Moller, mens han omvendt trak tæppet væk under Fritz Clausen og DNSAP. Foto: Arkivet ved Dansk Centralbibliotek for Sydslesvig.

tilknytning til DNSAP. Best skrev i sin beretning om dannelsen af regeringen Scavenius, at han havde drøftet med Frits Clausen, om der skulle stilles krav om, at medlemmer af DNSAP skulle forlanges indsat som ministre. Ifølge Best var de blevet fuldstændig enige om ikke at stille et sådan krav. Clausen skulle tværtimod have ønsket sig frie hænder til at fremme sin bevægelse. ${ }^{62}$ Bests fremstilling af mødet mellem ham og Clausen viser både, at han var i stand til at kontrollere Clausen, og at han var i stand til at styre situationen, således at den tjente hans egne interesser. Clausens bestræbelser på at påvirke de tyske myndigheder i forbindelse med Telegramkrisen viser, at han selv har været interesseret at komme til magten i november 1942. Da Hitler havde ytret ønske om, at DNSAP skulle overtage magten i Danmark, har det været vigtigt for Best - og det tyske udenrigsministerium - at fremstille situationen således, at det var Clausens eget forslag, at DNSAP blev holdt uden for den nye regering. Best havde 
bestemt sig for ikke at satse på Clausen som samarbejdspartner. Han skrev i sine egne erindringer om tiden i Danmark, at han allerede før sin ankomst havde besluttet ikke at satse på DNSAP, men derimod "... satte dem i skammekrogen ${ }^{63}$

Best var kynisk $i$ forhold til Frits Clausen. I en indberetning den 13. februar 1943 om det kommende folketingsvalg skrev Best om DNSAP: »... men selvom partiet kun bevarer sit hidtidige stemmetal, vil dette ikke forringe dets anvendelighed som redskab for den tyske politik. Dets betydning ligger ikke i dets størrelse, men i dets eksistens, hvorved de øvrige partier henholdsvis befolkningsgrupper underkastes et vist pres. ${ }^{64}$ Bests kommentar viser, at han ingen intentioner havde om at overlade magten til Clausen. DNSAP skulle, så længe det kunne bruges, være den trussel, som Best kunne anvende mod samarbejdspartneren Scavenius. Clausen havde derved ingen mulighed for at komme til at overtage magten i Danmark.

Møller og Best udviklede et godt forhold til hinanden. Den tyske konsul Lanwar beskrev forholdet mellem de to som sintimt kammeratlig “. Lanwar mente, at det positive forhold ville bevirke, at de tyske myndigheder ikke mere behøvede at frygte, at Møllers følelsesbetingede politiske metoder ville udløse "udenrigspolitiske ubehageligheder $\ll .65$

Jens Møller karakteriserede selv forholdet som fortroligt og betonede, at Best kaldte ham »Kammerat Møller«. Mindretallet har fornemmet en mere imødekommende tone fra den nye rigsbefuldmægtigede end fra forgængeren over for mindretallet. Møller arbejdede i 1942 på at opnå fuldstændig kulturel autonomi for det tyske mindretal i Sønderjylland. Best var imødekommende over for ønsket, hvilket fik Rudolf Stehr fra mindretallet til at arbejde videre med planerne. Fra den 8. december 1942 findes et dokument, som viser, at planerne om kulturel autonomi handlede både om skoleforhold, kirkeforhold og om, at mindretallet ønskede en repræsentant i det danske statsministerium. ${ }^{66}$

Mindretallet havde med Bests ankomst fået nye muligheder for at komme målet om en grænserevision nærmere. Det havde derved fået en øget handlefrihed i forhold til de danske myndigheder til at opnå dets nationale mål. Det virker desuden som om mindretallet - gennem det gode forhold mellem Møller og Best - fik styrket dets position i forhold til de tyske myndigheder. Bests ankomst til Danmark ændrede styrkeforholdet mellem DNSAP og NSDAP-N. Mens Clau- 
sen mistede sin politiske indflydelse og blev sat ud på sidelinjen, fik NSDAP-N større handlefrihed og styrket sin position over for de danske myndigheder. DNSAP's dansk-nationalistiske holdninger var nu en forhindring over for de tyske myndigheder for at opnå indflydelse. Best havde valgt at samarbejde med Scavenius, hvorved DNSAP kun var et instrument til at sørge for, at samarbejdspartneren gjorde, hvad Best forventede af ham. DNSAP's manglende politiske muligheder medførte samtidig, at partiet var svækket i konkurrencesituationen med NSDAP-N.

\section{Folketingsvalget 1943}

Den 25. januar 1943 henvendte Scavenius sig til Best angående et dansk ønske om at afholde folketingsvalg $\mathrm{i}$ foråret 1943. Best mente selv, at det ville være en god idé at opfylde det danske onske, da der - ifølge dansk lovgivning - ellers ikke ville være en lovgivende myndighed i Danmark efter den 3. april 1943. Det ville betyde, at den fremtidige danske lovgivning ville kunne blive erklæret ugyldig af en domstol, hvilket ikke ville være i tysk interesse. ${ }^{67}$ For Best var valget en mulighed for at demonstrere over for det tyske udenrigsministerium, at han havde kontrol med situationen i Danmark.

I Bests indberetning den 29. januar 1943 kom det frem, at der var skepsis i Berlin over for afholdelsen af valget i Danmark. Best holdt dog fast $i$, at valget ville virke som et dansk initiativ, og at et forbud mod valget ville medføre større indre politiske uroligheder end afholdelsen af valget. Det tyske udenrigsministerium var dog fortsat skeptisk og forlangte at vide, hvor stor en tilvækst Best forventede, at DNSAP kunne opnå ved valget, og om det kunne forhindres, at tyskfjendtlige partier ville få fremgang. Best forklarede i sit svar, at Clausen regnede med at få en stemmefremgang ved valget. Han pointerede samtidig, at partiet ikke stræbte efter at komme i regering. Han slog yderligere fast, at hvis samlingspartierne ville få en overvejende del af stemmerne, betød det en positiv folkeafstemning i forhold til Scavenius. I en notits fra den tyske gesandt, Werner v. Grundherr, angående det kommende danske folketingsvalg påpegede han, at DNSAP's resultat ved folketingsvalget ville vise, om det »... drejer sig om et procentvis svagt parti«. Det kommende folketingsvalg skulle vise, om partiet havde en politisk fremtid, eller om det havde mistet sin betydning. Best kritiserede desuden det tyske udenrigsministeriums standpunkt i sagen om det danske folke- 
tingsvalg. Han hævdede, at det tyske udenrigsministerium var imod afholdelsen af valget, fordi det ikke undte Best et resultat i denne sag. Dette illustrerer, at selve afholdelsen af valget var blevet en personlig prestigesag for Best. ${ }^{68}$

I et telegram fra den 11. marts 1943 skrev Best, at Clausen forventede at gå fra tre mandater til mellem otte og 15 mandater, hvilket Best ikke anså for realistisk. Best mente, at DNSAP mindst ville få tre mandater igen og maksimalt få fordoblet antallet af stemmer og mandater. ${ }^{69}$ Best mente ikke, at partiet havde mulighed for at opnå en stor opbakning hos den danske befolkning. DNSAP forsøgte gennem agitation og politiske møder at få det ønskede resultat ved folketingsvalget. I det nazistiske partiorgan, National-Socialisten, hed det den 11. marts 1943: "Afregningen sker nu den 23. marts. Lad det spredes, at nu forstod det danske folk, under tidehvervets mægtige bølge, at foretage det absolut nødvendige vagtskifte. " DNSAP havde tre politiske møder i Aabenraa Politikreds, men ingen af dem samlede større tilslutning fra ikke-medlemmer af DNSAP eller NSDAP-N. Næsten alle tilhørere var medlemmer af enten DNSAP eller det tyske mindretal, som var mødt talstærkt op. På selve valgdagen var der ingen sammenstød mellem dansksindede og tysksindede. Enkelte valgsteder indfandt der sig medlemmer af DNSAP, som af sysselledere var blevet beordret til at overvåge valghandlingerne. De blev dog hurtigt vist væk. Valget den 23. marts 1943 blev en succes for Scavenius' samlingsregering, mens DNSAP trods en stemmefremgang ikke formåede at få mere end de tre mandater, de havde i forvejen. ${ }^{70}$

I sin indberetning i maj 1943 gjorde Best det klart, at Clausen havde vist sin manglende politiske evne ved ikke at indrette målsætning, organisation og arbejde efter de politiske forhold i Danmark. Ifølge Best havde den tyske støtte til DNSAP samtidig fået den danske befolkning til at betragte DNSAP som et betalt redskab for tyskerne. Modviljen mod partiet havde derudover udviklet sig til foragt, da partiet havde brugt den tyske hjælp til en »overdådig livsførelse «. Desuden havde DNSAP kun mulighed for at opnå en politisk fremtid, hvis partiet klarede sig uden tysk støtte og selv begyndte at hverve medlemmer. ${ }^{71}$ Bests kritik af Clausen var total. Han udnyttede det forventede valgresultat til fuldstændigt at fjerne DNSAP som en politisk faktor i Danmark. DNSAP havde desuden mistet indflydelse på hvervninger, hvilket gjorde, at partiet nu var uinteressant for de tyske instanser. 
NSDAP-N så folketingsvalget i 1943 som en mulighed for at realisere ønsket om større kulturel autonomi for det tyske mindretal i Sønderjylland. Da det begyndte at se ud, som om valget ville blive gennemført, rejste Jens Møller derfor i en skrivelse til VoMi spørgsmålet om oprettelsen af et tysk kontor under det danske statsministerium, der skulle tage sig af mindretallets anliggender. Mindretallet kunne efter Møllers mening ikke deltage i et kommende valg, da en stor del af mindretallet var beskæftiget uden for Sønderjylland med opgaver, som støttede den tyske krigsførelse. Best var misfornøjet med, at mindretallet valgte at gå til VoMi i Berlin i stedet for den rigsbefuldmægtigede $\mathrm{i}$ København. Da han allerede tidligere havde vist sig imødekommende over for ønsket om mindretallets autonomiplaner, kan det virke mærkeligt, at Møller valgte at sende indberetningen om valget til VoMi. Noack mener, at det skyldtes, at han frygtede, at Best ville undgå at vanskeliggøre folketingsvalget yderligere ved at kræve oprettelsen af et tysk kontor. Det er meget sandsynligt, at Best ikke var interesseret $i$ at risikere sit prestigeprojekt ved at komplicere det yderligere med mindretallets ønske om et tysk kontor. Best har vidst, at forslaget ville møde modstand blandt de danske parlamentarikere. Desuden havde mindretallet traditionelt haft en tættere kontakt til VoMi end til det tyske udenrigsministerium, hvilket kan have medvirket til, at det valgte at gå direkte til denne tyske instans i Berlin. ${ }^{72}$

Best bakkede efterfølgende op bag Møllers ønske om oprettelsen af det tyske kontor. I et telegram til det tyske udenrigsministerium den 24. februar 1943 fortalte Best, at Møller allerede havde henvendt sig til Scavenius angående sagen. Best havde derefter drøftet sagen med Scavenius, hvor Scavenius havde erklæret, at planen var mulig at realisere. Sagen kunne altså løses »tvangfrit« i forbindelse med ordningerne omkring valget. Best påpegede, at Møllers ønsker ikke var i modstrid med Bests forslag om at tillade folketingsvalget. Ifølge Best var Møller enig $i$ hans politiske og retslige holdninger til at afholde valget. ${ }^{73}$ Det har været vigtigt for Best at vise, at han havde kontrol over situationen i Danmark. Best var desuden meget opmærksom på at pointere, at Møllers forslag ikke ville støde på vanskeligheder hos den danske regering.

Forslaget mødte dog modstand fra de danske parlamentarikere. I et brev til det danske udenrigsministerium den 25 . februar 1943 slog redaktør Bjørn Svensson fast, at mindretallets forslag ville medføre, 
at mindretalsspørgsmål fremover gik fra at være indre dansk politik til at blive dansk-tyske anliggender. Derudover ville det tyske mindretal få en særstatus i det danske samfund, som dets størrelse slet ikke berettigede til, og som det danske mindretal syd for grænsen aldrig ville kunne opnå. Scavenius foreslog Møller et kompromisforslag, hvor det tyske mindretal i Sønderjylland efter det kommende valg $i$ en bekendtgørelse sikredes en nær forbindelse med regeringen og Folketinget. Møller afslog forslaget, hvorefter Best kontaktede Scavenius og gjorde ham det klart, at Bests egne instrukser fra Berlin sagde, at man skulle finde en tilfredsstillende løsning, for at valget kunne finde sted. Scavenius holdt efterfølgende et ministermøde, der resulterede $i$, at man fra dansk side kom med et udkast, der imødekom mindretallets onske om oprettelse af et tysk kontor under Statsministeriet. Møller accepterede nu det danske udkast og kaldte det for en historisk dag for mindretallet. ${ }^{74}$

I et telegram fra Himmler til lederen af VoMi, Werner Lorenz, den 11. marts 1943 blev det meddelt, at Himmler nu forventede, at mindretallet stemte på de danske nazister ved det kommende valg, da DNSAP ikke måtte opleve en tilbagegang. Best gik ind for, at mindretallet stillede op på DNSAP's liste, men gjorde det frit for Møller, hvordan han ville tilrettelægge samarbejdet. Møller var dog ikke interesseret $i$ at støtte DNSAP. På et underførermøde den 14. marts 1943 i NSDAP-N ville Møller oprindeligt have opfordret til, at mindretallet undlod at deltage $\mathrm{i}$ valget for at vise loyalitet over for den aftale, man havde indgået med den danske stat om oprettelsen af det tyske kontor. Han ville true med udelukkelse af mindretallet, hvis der var medlemmer, som alligevel valgte at stemme. Han nøjedes dog med at argumentere for, hvorfor mindretallet skulle lade være med at stemme, samtidig med at han viste forståelse for, at der var dele af mindretallet, som ville stemme på DNSAP. Han slog dog fast, at Clausen var "brændemærket " som en partifører, der var afhængig af Berlin. Efter Møllers personlige opfattelse ville man gøre Clausen en bjørnetjeneste ved at stemme på DNSAP. ${ }^{75}$

Det var lykkedes Møller at spille de tyske instanser ud mod hinanden og derved få Best til at tvinge den danske regering til at efterkomme mindretallets onske ved valget. Herved havde mindretallet opnået en særstatus i det danske samfund. Styrkeforholdet mellem de to partier var nu entydigt ovre på NSDAP-N's side, der udnyttede lejligheden til at forsøge at svække DNSAP yderligere. Hvor DNSAP 
i 1941 havde været $\mathrm{i}$ offensiven over for NSDAP-N, var det nu omvendt. Det ses, at modsætningsforholdet mellem de to partier fortsat var stort. NSDAP-N var via en aftale med den danske stat kommet tættere på virkeliggørelsen af deres nationale politiske mål samtidig med, at DNSAP mistede sin sidste politiske betydning som samarbejdspartner for de tyske instanser.

\section{Afslutningen}

Frits Clausen var ikke selv i tvivl om, at valgresultatet ville få konsekvenser for DNSAP's videre politiske skæbne, hvilket fik ham til at sende et brev til Best kort efter valget, hvori han gav sin begrundelse for valgresultatet. Valget havde, som Clausen frygtede det, udviklet sig til en folkeafstemning for demokratiet mod det autoritære system, som Tyskland repræsenterede. Clausen kritiserede desuden de tyske myndigheder for ikke at have givet ham tilstrækkelig frihed til at angribe samlingspartiernes politik. Clausen benyttede samtidig lejligheden til at udtrykke sin mistillid til den politik, som SS førte i Danmark. Oprettelsen af de germanske korps i 1943 var efter Clausens mening et dårligt skridt, som ville skabe uro i befolkningen. Clausen havde fäet den fornemmelse, at dannelsen af de germanske korps gjorde, at de frivillige fra DNSAP gik tabt for partiet, hvilket var i strid med de løfter, SS havde givet ham i 1941. Derudover havde den tyske økonomiske støtte betydet, at DNSAP af den danske befolkning blev betragtet som et betalt tysk redskab. Han regnede med, at han nu ville kunne føre en mere selvstændig politik ved at fravælge den tyske økonomiske støtte. ${ }^{76}$ Clausen havde erkendt, at DNSAP havde forpasset muligheden for at blive et troværdigt politisk parti ved at knytte partiet tæt til den tyske besættelsesmagt. Henning Poulsen siger i sin disputats, at Clausen hermed havde erkendt, »... at DNSAP ikke længere var i stand til at deltage $i$ det store politiske spil «. 77 Frits Clausen havde anerkendt, at han havde mistet sin politiske indflydelse.

Clausen mistede også betydning omkring hvervningerne, som han i foråret 1943 havde forsøgt at anvende som en sidste mulighed for at opnå indflydelse over for de tyske instanser. Han beklagede sig over, at frivillige blev flyttet fra Frikorps Danmark over i andre Waffen-SS divisioner. I et åbent brev til Clausen angående hvervningerne stod der: »Når du finder det opportunt, driver du hvervning af frivil- 


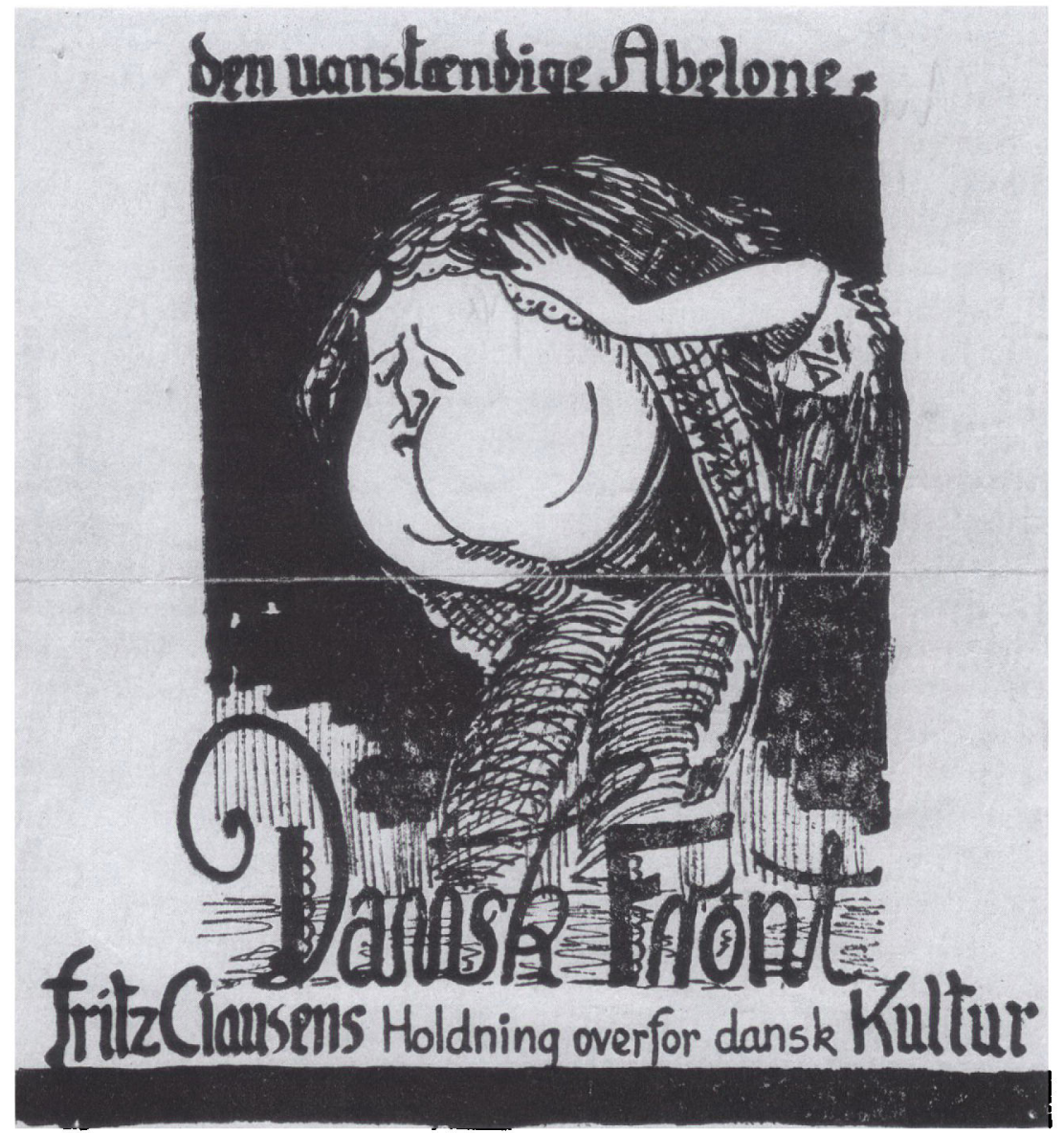

Frits Clausen og DNSAP fik aldrig storre folkelig opbakning. Det var vedblivende et problem under Besættelsen, idet den tyske besættelsesmagt ikke regnede partiet som noget reelt alternativ til samarbejdsregeringen. Som tegningen fra 1944 viser, blev der gjort grin med Clausen $i$ den illegale presse. Tegning: Historisk Samling fra Besættelsestiden 1940-45.

lige til østfronten. Det næste øjeblik, når du er fornærmet på Værnemagten, sender du partiledere ud for at sabotere hvervningen. Din hverveinteresse er ikke styret af idealisme.« I en fortrolig ledermeddelelse fra 19. april 1943 hed det, at "... de medlemmer af DNSAP, som eventuelt ønsker at indtræde i "Germansk Korps", fremtidigt ikke kan beklæde nogen tillidspost inden for partiet«. Der har altså været 
stor splittelse inden for DNSAP i forhold til, hvordan hvervningerne skulle forløbe.

Frits Clausen var samtidig blevet bekymret for sin egen sikkerhed i hjemmet i Bovrup. DNSAP forventede uro og usikkerhed. Politiadjudanten skrev den 6. maj 1943, at der var kommet en anmodning fra Bovrup om bevogtning af DNSAP's partihovedkvarter. Da politiadjudanten ingen konkrete trusler havde, blev der foranlediget en midlertidig natbevogtning ved to reservebetjente. ${ }^{78}$ Clausen var $i$ strid modvind, men forsøgte at kæmpe videre, indtil han gav op $i$ september 1943 og meldte sig som frivillig til fronten. Hans afgang som partifører betød, at partiet mistede sin sidste samlingskraft, hvorefter det oplevede en markant medlemsflugt og et udbrud af indre stridigheder. ${ }^{79}$

Mindretallet havde med oprettelsen af det tyske kontor under Statsministeriet fået styrket dets position i Danmark. Det havde samtidig i februar 1943 oprettet hjemmeværnet "Zeitfreiwilligendienst«, som skulle indsættes, hvis Danmark blev invaderet. Johan Peter Noack mener, at korpset skulle dæmme op for det dilemma, at Møller havde forpligtet hele den del af mindretallet, der kunne være tale om, til at melde sig til Waffen-SS. ${ }^{80}$ Det nye korps skulle bestå af den del af mindretallet, som enten var blevet erklæret for uundværlige eller var for gamle til fronttjeneste. I januar $1943 \mathrm{blev}$ der agiteret stærkt for, at de 17-60-årige i mindretallet skulle melde sig til hjemmeværnet. Møller kaldte samtidig den 5. marts 1943 til en forstærket indsats på hjemmefronten. Alle de hjemmetyske virksomhedsejere skulle stille deres virksomhed til rådighed for produktion til den tyske værnemagt. Mindretallet var derfor meget optaget af at stotte den tyske krigsindsats samtidig med, at det var i gang med at opbygge et hjemmeværn, som skulle give større sikkerhed for mindretallet i Sønderjylland. ${ }^{81}$

Den store omvæltning kom, da den danske regering trådte tilbage den 29. august 1943. Det kom som et chok for Møller, som i et brev den 21. september 1943 beklagede, at den danske parlamentariske regering var trådt tilbage. Han gav udtryk for, at han følte mindretallets arbejde som brobyggere til Norden truet. Han påpegede samtidig, at Best var den eneste politiker af format, der nød almindelig dansk tillid. Møller var nervøs for, hvad den nye situation ville betyde for mindretallet. Den politiske handlefrihed, som det havde opnået med oprettelsen af det tyske kontor, kunne være truet, hvis undtagelsestil- 
standen medførte en ny rigsbefuldmægtiget i Danmark. Møller ønskede at bevare den privilegerede position, som mindretallet havde opnået efter valget. Da Zeitfreiwilligendienst samtidig var blevet anvendt til bevogtningsopgaver $i$ forbindelse med undtagelsestilstanden den 29. august 1943, frygtede Møller for mindretallets sikkerhed. ${ }^{82}$

Det tyske mindretal blev mindre aggressivt i forholdet til den danske befolkning. Politiadjudanten skrev i november 1943: "Pessimismen med hensyn til krigens udfald synes at brede sig blandt det tyske mindretal, »tonen « er blevet betydelig mere sagtmodig. Skriftlige henvendelser før på tysk, affattes nu på dansk og er nu underskrevet ærbødigst i stedet for heil Hitler.«83

NSDAP-N havde kunnet anvende den tyske besættelsesmagt til at skaffe sig en særstatus i Danmark, som den nu frygtede var truet, hvis den danske regerings afgang medførte, at den rigsbefuldmægtigede blev udskiftet. Samtidig led Tyskland store nederlag, især på østfronten, og det bevirkede, at krigens udfald var uvis. Det fik mindretallet til at ændre tonen over for de danske myndigheder. Clausens afgang til fronten medførte indre stridigheder i DNSAP. NSDAP-N var samtidig begyndt at fokusere på at beskytte mindretallet mod farer udefra og anvende det tyske kontor til at få dets ønsker igennem. Derved havde modsætningsforholdet mellem de to partier mistet sin betydning, og konkurrenceforholdet til de tyske myndigheder var samtidig uden betydning, da DNSAP nu var uden politisk betydning.

\section{Sammenfatning}

Konkurrenceforholdet mellem de to partier hang sammen med de muligheder, som situationen i Danmark gav dem til at få opfyldt deres nationale politiske mål. Samtidig havde de to partiers styrkeforhold stor betydning for partiernes mulighed for at konkurrere indbyrdes. Da Danmark opgav modstanden mod Tyskland den 9. april 1940, blev der skabt en speciel situation i Danmark. Den danske stat fik territorial integritet og politisk uafhængighed, hvilket betød, at den danske stat kunne fortsætte med selv at tage sig af landets interne sager. De to partier var derved kommet i en situation, hvor medlemmerne som statsborgere i Danmark skulle fungere under den danske stat, alt mens de kunne udnytte kontakten til den tyske besættelses- 
magt til at få deres ønsker igennem over for den danske stat. Styrkeforholdet mellem de to partier hang sammen med, hvor stor betydning de tyske myndigheder gav dem i det politiske spil. DNSAP fik styrket sin position under hvervekampagnerne i 1941, men formåede ikke at anvende denne position til at komme tættere på magten i Danmark. NSDAP-N kom i modvind hos SS i flere omgange, men kunne trække sig sejrrigt ud af konflikterne, da de udenrigspolitiske interesser $i$ at bevare et stærkt mindretal dominerede over SS' onsker om flere frivillige. Den afgørende forskel mellem NSDAP-N's og DNSAP's styrkeforhold har været, at mens NSDAP-N kontrollerede hele mindretallet, havde DNSAP kun en marginal opbakning i den danske befolkning. DNSAP stod gennem hele perioden svagere end NSDAP-N i forhold til de tyske myndigheder på grund af partiets manglende evne til at opnå en bred opbakning samt den danske befolknings modvilje mod partiet. Det store problem for DNSAP var, at samlingspartierne formåede at tilfredsstille de tyske myndigheders kortsigtede militære, udenrigspolitiske og økonomisk mål på en måde, som de tyske myndigheder ikke havde tiltro til, at DNSAP ville kunne gøre det.

Der var ikke noget samarbejde mellem de to partier ud over de koordinerende møder om hvervekampagnerne, som SS holdt med begge partier. Der var et køligt forhold mellem de to partier, hvilket skyldtes, at partierne har vogtet på modpartens handlinger og reageret så snart, de følte deres egen interesser truet. Konkurrencen mellem de to partier om de tyske myndigheders gunst har derfor også haft stor betydning for forholdet mellem de to partier.

Det er altså muligt at se, hvordan forholdet mellem DNSAP og NSDAP-N udviklede sig i perioden til 1943 ved at se på, hvordan de agerede over for de tyske og de danske myndigheder. De to partier blev spillet ud mod hinanden af de tyske myndigheder og instanser i flere tilfælde, hvilket gjorde, at partierne følte deres nationale interesser truet. Partierne havde kun mulighed for at opnå politisk indflydelse gennem de tyske myndigheder. Den fælles ideologi gjorde det samtidig vigtigt for partierne at markere de divergerende nationale politiske mål for ikke at risikere, at disse mål kom i baggrunden i forhold til ideologien. De to partier var begge bygget op omkring nationale politiske mål, hvilket medførte, at partiførerne skulle vise resultater $\mathrm{i}$ forhold til disse mål for ikke at miste autoritet i deres parti. De forskellige nationale politiske mål var derfor centrale $i$ forståelsen af forholdet mellem de to partier. 


\section{LITTERATUR}

Best, Werner (1989): Danmark $i$ Hitlers hånd. Rigsbefuldmægtiget Werner Bests beretning om sin besattelsespolitik $i$ Danmark, med portratter af Hitler, Göring, Ribbentrop, Himmler, Heydrich, Scatrenius og Quisling. Holkenfeldts Forlag. Kabenhavn.

Bohn, Robert m.fl. (red.) (2001): Nationale mindretal i det dansk-tyske grænseland 1933-1945. Institut for Grænseregionsforskning. Aabenraa.

Bundgård Christensen, Claus m.fl. (2005): Danmark besat. Krig og hverdag 1940-45. Høst og Søn. København.

Carstensen, Chr. M. (1942): Nordschleswigs Sendung im grossgermanischen Reich. Landsarkivet for Sonderjyllands Tryksamling.

Chodakiewicz, Marek Jan (2004): Between Nazis and Soviets. Occupation politics in Poland, 1939-1947. Lexington Books. Lanham.

Danker, Uwe og Astrid Schwabe (2005): Schleswig-Holstein und der Nationalsozialismus. Wachholtz Verlag. Neumünster.

Fink, Troels (1955): Sønderjylland siden genforeningen i 1920 . J. H. Schultz. København.

Kirchhoff, Hans (2002): Samarbejde og modstand under besættelsen. En politisk historie. Odense Universitetsforlag. Odense.

Komjathy, Anthony and Rebecca Stockwell (1980): German minorities and the Third Reich. Ethnic Germans of East Central Europe between the wars. Holmes \& Meier. New York.

Lauridsen, John T. (2002): Dansk nazisme 1930-45 - og derefter. Gyldendal. København.

Lauridsen, John T. (2003): "Foreren har ordet!«. Frits Clausen om sig selv og DNSAP. Museum Tusculanums Forlag. Kobenhavn.

Lauridsen, John T. (2006): „DNSAP i spil. Frits Clausens beretning om tiden efter 9. april 1940«, Danske Magazin. 50, h. 1. 2006. s. 163-301.
Lauridsen, John T. (2007): Over stregen under besættelsen. Gyldendal. København.

Lauridsen, John T. (2008): "')Dansk nazismes største sejr $«$. Frits Clausen og grænserøret juni 1940«, Sønderjyske Arbøger 2008, s. 184-214.

Lorek, Sabine (1998): Rechtsabrechnung - Retsopgor. Politische Säuberung nach dem zweiten Weltkrieg in Nordsleswig. Wachholtz Verlag. Neumünster.

Lund, Joachim (2003): Partier under pres. Demokratiet under besættelsen. Gyldendal. København.

Luther, Tammo (2004): Volkstumspolitik des Deutschen Reiches 1933-1938. Die Auslanddeutschen im Spannungsfeld zwischen Traditionalisten und Nationalsozialisten. Steiner Verlag. Stuttgart.

Noack, Johan Peter (1974): Det tyske mindretal $i$ Nordslesvig under besattelsen. Munksgaards Forlag. København.

Poulsen, Henning (1970): Besættelsesmagten og de danske nazister. De politiske forhold mellem tyske myndigheder og nazistiske kredse $i$ Danmark 1940-43. Gyldendal. København.

Poulsen, Henning (2006): "Det tyske hvervekontor i Danmark «, Danske Magazin. 50, h. 1. 2006. s. 135-162.

Ravn, Ole (2007): Forer uden folk. Frits Clausen og Danmarks National Socialistiske Arbejder-Parti. Syddansk Universitetsforlag. Odense.

Schultz Hansen, Hans m.fl. (red.) (2009): Senderjyllands Historie 2. Efter 1815. Historisk Samfund for Sonderjylland. Aabenraa.

Strand, Frederik (2006): Forerens germanske arm. SS i Danmark. Høst. København.

Thomsen, Erich (1971): Deutsche Besatzungspolitik in Dänemark 1940-1945. Bertelsmann. Düsseldorf.

Thomsen, Birgitte Herreborg og Henrik Skov Kristensen (red.) (2010): Senderjylland $i$ 1933. Historisk Samfund for Sønderjylland. Aabenraa. 


\section{KILDESAMLINGER}

[PK.2]: Beretning til Folketinget afgivet afden af Tinget under 25 . oktober 1950 nedsatte Kommission i henhold til Grundlovens $\S 45$. 1954. Bd. 2: Supplement: forholdene ved Danmarks besættelse. Schultz. Kebenhavn.

[PK.4]: Beretning til Folketinget afgivet afden af Tinget under 25 . oktober 1950 nedsatte Kommission i henhold til Grundlovens $\S 45$. 1954. Bd. 4: Regering og Rigsdag under besættelsen. Schultz. Kobenhavn.

[PK.7]: Beretning til Folketinget afgivet afden af Tinget under 25 . oktober 1950 nedsatte Kommission i henhold til Grundlovens $§ 45$. 1954. Bd. 7: Justitsministeriet og retshåndhævelsen under besættelsen. Schultz. København.

[PK.12]: Beretning til Folketinget afgivet afden af Tinget under 25 . oktober 1950 nedsatte Kommission i henhold til Grundlovens $\S 45$. 1954. Bd. 12: 9 . april 1940 - tyske dokumenter. Schultz. København.

[PK.13]: Beretning til Folketinget afgivet afden af Tinget under 25 . oktober 1950 nedsatte Kommission i henhold til Grundlovens § 45. 1954. Bd. 13: Supplement til de tidligere afgivne beretninger IV-XI vedrorende regering og rigsdag samt forskellige ministerier under besættelsen - dansk oversættelse. Schultz. København.

[PK.14]: Beretning til Folketinget afgivet afden af Tinget under 25 . oktober 1950 nedsatte Kommission i henhold til Grundlovens $§ 45$. 1953. Bd. 14: Det tyske mindretal under besættelsen: Tyske og danske dokumenter - Danske dokumenter og oversættelser af tyske dokumenter. Schultz. København.

\section{ARKIVMATERIALE FRA LANDSARKIVET FOR SØNDERJYLLAND}

Politiets Efterretningstjeneste, Bovruparkivet, pakke R417: Redegørelser vedrørende Bovruparkivet 19331950.

Danmarks Nationalsocialistiske Arbejderparti: Nazistiske blade og tidsskrifter: Grænsen.

DG05: Politiadjudant sønderjyske landsdel 1940-1944: Indberetninger til Rigspolitichefen og Justitsministeriet. nr. 253, 221.

DG05: Politiadjudant sønderjyske landsdel 1940-1944: 1940-1945 rapporter vedr. Nordslesvig. nr. 277.

DG06: 1940-1945 Politikommandøren for Sydjylland: indberetninger til statsadvokaten for særlige anliggender. nr. 345.

S\%C3\%B8nderiylland_en arkivoversigt.pdf (3. juli 2010)

\section{NOTER}

1. Den Parlamentariske Kommissions beretninger (herefter PK.) 14, nr. 66.

2. Schultz Hansen, 2009, s. 339-42.
3. PK. 14, nr. 21, 24. DG06: Indberetninger: 20. maj 1940.

4. Volksdeutsche Mittelstelle var et 
tysk regeringsbureau, der tog sig af kontakten til de tyske mindretal uden for Tyskland.

5. PK. 12, nr. 45, 89. PK.12, nr. 20, 30.

6. Bovruparkivet: Magtovertagelsen. Lauridsen, 2003, s. 649-659.

7. lbid.

8. PK. 7, nr. 114. PK.14, nr. 39.

9. Bovruparkivet: Magtovertagelsen.

10. Ibid.

11. Ibid.

12. PK. 13, nr. 128 og 134.

13. PK. 13, s. 50 . Poulsen, 1970 , s. 385389.

14. PK. 14, nr. 30.

15. Noack, 1974, s. 31-43.

16. PK. 14, nr. 36 og 40. DG05: 1940-1944 Indberetninger til Rigspolitichefen og Justitsministeriet: juni 1940.

17. PK. 14, nr. 37.

18. PK. 14, nr. 41.

19. PK. 14, nr. 35 og 43.

20. Lauridsen, 2006, s. 259-260, 262 og 278.

21. Efterretningsofficer i den tyske sikkerhedspoliti, Sicherheits Dienst (SD).

22. PK. 14 , nr. 42 . Lauridsen, 2008, s. 204.

23. Lauridsen, 2006, s. 271.

24. PK. 14, nr. 38-39.

25. PK. 14, nr. 42 og 44.

26. PK. 13, nr. 128 og 134. Ravn, 2007, s. 106.

27. Ravn, 2007, s. 309-310. Poulsen, 2006, s. 135-136.

28. PK. 14, nr. 263-265.

29. PK. 14, nr. 21 og 280. DG06: 19401945 indberetninger: 10 . juni 1940.

30. PK. 2, nr. 7a.

31. Lauridsen, 2007, s. 593.

32. Lauridsen, 2006, s. 234-236.

33. Bovruparkivet: Hvervning.

34. Poulsen, 2006, s. 136-137, 142 og 145146. PK. 14, nr. 269.

35. PK. 14, nr. 66.

36. Poulsen, 2006, s. 146-150.

37. Poulsen, 2006, s. 151-154. PK. 4, nr. 51. Poulsen, 1970, s. 280-282.

38. Poulsen, 1970 , s. 284.

39. Poulsen, 2006, s. 155-158. Lauridsen, 2002, s. 69. Strand, 2006, s. 124.

40. Ravn, 2007, s. 341-342. PK. 13, nr. 204, 206 og 208.

41. PK.13, nr. 209.
42. Poulsen, 1970, s. 294-295.

43. PK. 13, s. 310-311.

44. Ravn, 2007, s. 343-345. Bovruparkivet: Hvervning.

45. PK. 13, nr. 222 og 227.

46. Noack, 1974, s. 102-103.

47. Citatet kan oversættes til "... at der var en forstærket spænding til den tyske folkegruppe $i$ Nordslesvig, og via et medlem af partirådet var de oppositionelle forhold bekendt her .....

48. Poulsen, 2006, s. 147. Noack, 1974, s. 103.

49. PK. 14, nr. 277 og 286. Noack, 1974, s. $103-104$.

50. PK. 14, nr. 297-299.

51. DG06 1940-1945 indberetninger: 5. december 1941.

52. Det kan oversættes til »... ikke kæmper for en uretmæssig grænserevision. Partiledelsens egoistiske grænserevisionsmål er ikke målet for de kampende tropper, idet de folketyske nordslesvigere kxmper for Tyskland og for et stortysk rige."

53. Noack, 1974, s. 109. Carstensen, 1942, s. 21, 32. Det kan oversættes til "... At finde sammen med Frits Clausen på en frolles vej pã et nationalsocialistisk grundlag. ... Under Frits Clausen begynder bekendelsen til en tysk-nordisk enhed at vare dominerende."

54. PK. 14, nr. 84.

55. PK. $14, \mathrm{nr} .86-89$.

56. PK. 13, nr. 308. Poulsen, 1970, s. 338.

57. Poulsen, 1970, s. 347. Ravn, 2007, s. 355.

58. Poulsen, 1970, s. 353, 374 og 378. Ravn, 2007, s. 403. Strand, 2006, s. 132.

59. Noack, 1974, s. 114-115 og 144-149. Ravn, 2007, s. 384-389.

60. PK. 13, nr. 328-329.

61. PK. 13, nr. $335,343$.

62. PK. 13, nr. 361.

63. Best, 1989, s. 61 og 316-317.

64. PK. 13, nr. 386.

65. PK. 14, nr. 99.

66. Lauridsen, 2007, s. 597. PK. 14, nr. 186-187.

67. PK. 13, nr. 376.

68. PK. 13, nr. 379 og 385-388.

69. PK. 13, nr. 393.

70. PK. 13, nr. 396. Bovruparkivet: National-Socialisten og Kamptegnet 
1943-1945. DG06 1940-1945 indberetninger: april 1943.

71. PK. 13, nr. 397 og 400.

72. PK. 4, nr. 144-145. Noack, 1974, s. 146.

73. PK. 14, nr. 146.

74. PK. 14, nr. 146-151.

75. PK. 14, nr. 155-159.

76. PK. 13, nr. 400 og 404. Lauridsen, 2003, s. 722-726.

77. Poulsen, 1970, s. 383.

78. Bovruparkivet: Hvervning. DG06
1940-1945 indberetninger: 6. maj 1943. Lauridsen, 2003, s. 727.

79. Poulsen, 1970, s. 383. Bovruparkivet: Hvervning.

80. Noack, 1974, s. 118. PK.14, nr. 363.

81. DG06 1940-1945 indberetninger: 5 . april 1943.

82. PK. 14, nr. 124-125 og 373.

83. DG05: 1940-1944 Indberetninger til Rigspolitichefen og Justitsministeriet: november 1943.

\section{Zusammenfassung}

Das Aufblühen des Nazismus in Deutschland, die finanzielle Krise und der nationale Konflikt im Grenzgebiet zwischen Dänemark und Deutschland bildeten die Grundlage zur Bildung kleiner nationalsozialistischer Parteien in Dänemark. DNSAP, die dänische Kopie der deutschen Nazi-Partei, NSDAP, hatte starke dänisch-nationale Wurzeln. NSDAP-N entstand innerhalb der deutschen Minderheit in Sonderjylland als Folge einer Zusammenlegung und Gleichrichtung der bisher bestehenden Minderheitenparteien. Durch die Besatzung eröffneten sich für beide Nazi-Parteien neue Möglichkeiten und Herausforderungen. Sie erkannten schnell die Möglichkeit, ihre nationalpolitischen Ziele durch die deutsche Besatzungsmacht zu erreichen. NSDAP-N wollte die Revision der deutsch-dänischen Grenze, DNSAP strebte danach, die Macht in Dänemark zu übernehmen. Beide Parteien waren aber ganz und gar von deutscher Unterstützung abhängig. 